\title{
JÓZEF BANIAK \\ Świadomość religijna dzisiejszych gimnazjalistów polskich.
Studium socjologiczne na przykładzie Kalisza i okolic
}

\section{Założenia teoretyczne i metodologiczne}

Gimnazjaliści są odrębna grupa czy kategorią młodzieży, lokującą się we wczesnym okresie dorastania osobniczego, który odznacza się specyficznymi cechami. Jan Śledzianowski pisze, że Gimnazjaliści sq dziećmi wspólczesnej Polski, tej po 1989 roku. Wprawdzie zasadniczy ich rocznik urodzenia, to 1986 rok, a więc w świadomości dzieci okresu po-niemowlęcego nie mógł się zapisać czas przeżywany w PRL. Może on być jeszcze przywolywany we wspomnieniach rodziców, ludzi dorostych (...). Wlaśnie ci mlodociani z końca XX wieku na przelomie tysiącleci, przeżywaja indywidualnie swój wlasny przelom, bowiem prawem naturalnego rozwoju jest, $i \dot{z} z$ dziecinstwa przechodza $w$ wiek mlodzieńczy ${ }^{1}$. Gimnazjaliści, to mlodzi ludzie, którzy weszli wlaśnie w trudny okres wczesnego dorastania, przestając już „być dziećmi” i stając się stopniowo „osobnikami młodzieńczymi". Okres, w którym znajdują się gimnazjaliści, odznacza się radykalnymi, szybkimi zmianami, niemal w każdej sferze ich życia osobniczego i spolecznego. M. Taraszkiewicz stwierdza, że w okresie dorastania, już w poczatkowym jego etapie, ksztaltuje się tożsamość jednostki, jako podstawowa cecha jej osobowości i zasada funkcjonowania oraz kryterium oceny wlasnej. Okres dorastania, zdaniem tej autorki, to czas intensywnego poznawania własnej osoby, odnajdowania wlasnego miejsca w spoleczeństwie, poszukiwania celu i sensu własnego istnienia, a także swojej roli w życiu, inicjowania bardziej skrystalizo-

${ }^{1}$ Zob. J. Ś le d z i a n o w sk i: Aspiracje życiowe gimnazjalistów. Kielce 2001 s. 5. 
wanych, niż w dzieciństwie, planów na przyszłość, bliższych i dalszych czasowo $^{2}$.

W okresie wczesnego dorastania mloda jednostka przechodzi skomplikowany proces zmian biologicznych, psychicznych, emocjonalnych, spolecznych i moralnych w strukturze i funkcjonowaniu swojej osobowości. Zmiany te, wlaśnie na tym etapie jej rozwoju, nabierają dużego przyspieszenia, które często jest niezrozumiale dla samej mlodej jednostki - dziewczyny i chlopca. Dlatego też prawidlowy rozwój mlodzieży w tym okresie wymaga wielorakiej pomocy ze strony osób doroslych, zwlaszcza rodziców, nauczycieli i wychowawców, jako osobników znaczacych w jej osobistym życiu i dorastaniu do dojrzałości. W tym trudnym okresie, rozlokowanym gdzieś między „,buntem i sprzeciwem", z jednej strony, a „potrzebą akceptacji i zrozumienia”, z drugiej strony, dorośli znaczący winni tym młodym osobom wykazać wiele wyrozumialości, życzliwości, empatii i miłości, a jednocześnie unikać czy wystrzegać się w kontaktach z nimi autorytarnych decyzji, moralizowania, stosowania niezrozumialych sankcji negatywnych, albo postawy obojętnej i lekceważacej problemy i potrzeby mlodzieży. R. Łapińska twierdzi, że dorośli, chcąc pomóc dorastajacej mlodzieży w pokonywaniu różnych trudności i klopotów codzienności, powinni pamiętać, że często popada ona w stany emocjonalno krańcowe. Radość jest żywiolowa, smutek graniczy z rozpaczq. Po okresie przygnębienia przychodzq okresy nadmiernego ożywienia. Mtodziez latwo przerzuca się od entuzjazmu do przygnębienia, od uczuć milości i uwielbienia, do nienawiśsi i pogardy ${ }^{3}$.W tym okresie, dodaje trafnie E. Hurlock, mlody czlowiek traci poczucie bezpieczeństwa, staje się lękliwy bardziej niż we wcześniejszym okresie swego rozwoju, staje się też mniej ufny, a jednocześnie zaczyna „liczyć” bardziej na siebie niż na pomoc doroslych, którzy traca autorytet $\mathrm{w}$ jego skali oceny ${ }^{4}$. W ocenie B.C. Lievegaed'a na etapie dorastania jasny, kolorowy, pelen kwiatów świat dziecka, zostaje zburzony, a mlody czlowiek spostrzega nagle nagi, szary świat tak zwanych konkretnych faktów ${ }^{5}$. Te wszystkie procesy zmian dokonują się w osobowości gimnazjalistów, liczących od 14 do 17 lat życia, które są dla nich trudne i zagadkowe do zrozumienia, choć także ich zadziwiają i intryguja. Jan Śledzianowski twierdzi, że gimnazjaliści znajdują się na swoistej „huśtawce" emocjonalnej, wywolanej ich etapem rozwoju osobniczego, zbytnio przyspieszonego nowymi sytuacjami życiowymi, w tym zmianą szkoły i jej otoczenia, odrębnymi egzaminami i lękiem o dostanie się do

${ }^{2}$ Zob. M. T araszkiewicz: Mlodzież o swojej przyszlości. „Psychologia Wychowawcza". R. 1985 nr 5 s. 521-522.

${ }^{3}$ R. Ł a p iń sk a: Psychologia wieku dorastania. Warszawa 1966 s. 28; por. R. Ł a p iń ska, M. Że brow sk a: Wiek dorastania. W: M. Ż e brow sk a (red.): Psychologia rozwojowa dzieci i mlodzieży. Warszawa 1986 s. 664-796.

${ }^{4}$ E. H u r 1 o c k: Rozwój dziecka. Warszawa 1975 s. 65-72.

${ }^{5}$ B.C.J. L i e v e g a e d: Fazy rozwoju dziecka. Torun 1993 s. 73. 
„wybranego" gimnazjum, a następnie, po jego ukończeniu, do liceum lub innej szkoly średniej. Z tej racji wymagają oni skutecznego wsparcia ze strony doroslych $-\mathrm{w}$ rodzinie i szkole ${ }^{6}$. Problem ten konkretyzuje i jasno precyzuje Maria Łopatkowa, twierdząc, że taka pomoc dla młodzieży powinna cechować każda matkę, każdego ojca, cale społeczeństwo $i$ wszystkie rzqdy ${ }^{7}$. Bez watpienia, wsparcie to jest im konieczne, gdyż wielu spośród ogólu gimnazjalistów nie sprostałoby samodzielnie nachodzacym ich trudnościom i zmianom w ich organizmie i psychice.

Ewa Wysocka twierdzi, że Mlodzież i młodość stanowi zjawisko biologiczne, społeczne i kulturowe, wyznaczane zmiennymi cywilizacyjnymi i kulturowymi, przelamujacymi sie $w$ systemie wychowania i socjalizacji ${ }^{8}$. Określenie to ulatwia zdefiniowanie i wyodrębnienie kategorii mlodzieży gimnazjalnej, znajdującej się na etapie rozwoju wczesnej adolescencji. Tak określona grupa młodzieży stanowi więc spoleczno-demograficzna kategorię osób w przejściowym stadium rozwoju między okresem dzieciństwa a dorostościq, przygotowujacq ja do przejęcia pelnej odpowiedzialności za własne życie, dokonywane wybory i podjęcia samodzielności spoleczno-ekonomicznej $j^{9}$. Młodzież w okresie dorastania, różniąc się od dzieci i doroslych, odznacza się, zdaniem licznych badaczy, specyficznymi cechami: krytycyzmem myślenia, nastawieniem perspektywicznym, skłonnością do krytycznej oceny zastanych wartości i proponowanych regul moralnych przez pokolenie starsze, kontestacją autorytetów, upartym poszukiwaniem własnej tożsamości, krytyczną oceną osób dorosłych i ich świata, w tym wlasnych rodziców i nauczycieli, wyodrębnianiem wlasnych zainteresowań i dążeń życiowych, w relacji do osób mlodszych i starszych, dążeniem do niezależności i samodzielności, wskazywaniem wad życia spolecznego w strukturach świeckich i religijnych, a także brakiem doświadczenia, pobudliwościa, krytykowaniem otaczajacej rzeczywistości. Ta chwiejność nastrojów, a jednocześnie kierowanie siẹ idealami i poszukiwanie wzorów odniesienia, cechują niemal każdą młodą osobę w tym wieku ,przyspieszonego" procesu dorastania, obejmujacego wszystkie sfery jej życia ${ }^{10}$.

${ }^{6}$ J. Ś 1 e d z i a n ow ski, dz. cyt., s. 5.

${ }^{7}$ M. L o p at k ow a: Pedagogika serca. Warszawa 1992 s. 102.

${ }^{8}$ E. W y s o c ka: Doświadczanie kryzysu w wartościowaniu a religijność mlodzieży szkól średnich. W: J. B a n i a k (red.): Religijna i moralna kondycja mlodzieży polskiej-mity i rzeczywistość. „Socjologia Religii”. R. 2005: 3 s. 49.

${ }^{9}$ Tamże, s. 49; por. W. A d a m s k i: Mlodzież wspólczesna. W: W. P o m y k a 1 o (red.): Encyklopedia Pedagogiczna. Warszawa 1993 s. 380.

${ }^{10}$ Zob. K. W i l e c k i: Spoleczne czynniki tożsamości pokoleniowej mlodzieży. „Studia Socjologiczne" R. 1990 nr 1-2; J. B a g r o w i c z: Edukacja religijna wspólczesnej mlodzieży. Torun $2000 ;$ K. S z a m b e l a n, M. T y s z k o w a: Samoocena uczniów w wieku dorastania i ich pozycja w grupie rówieśniczej. „Psychologia Wychowawcza”. R. 1974 nr 4; M. P rzet a c z n i k owa: Podstawy rozwoju psychicznego dzieci i mlodzieży. Warszawa 1978. 
E. H. Erikson twierdzi, że okres dorastania przygotowuje jednostkę do rozumnego i rozsądnego wejścia w dorosłe życie spoleczne oraz do odgrywania w nim stosownych ról spolecznych w każdej grupie odniesienia, w której przyjdzie jej funkcjonować. Podstawową cechą tego okresu, jego zdaniem, jest specyficzny kryzys tożsamości i rozproszenie ról. Efektem tego procesu może być albo integracja osobowości mlodej jednostki, czy jej tożsamości, albo kryzys tożsamości - dezintegracja osobowości ${ }^{11}$. W ocenie badaczy, kryzys ten bywa pokonywany przez młodą jednostkę z pomocą mechanizmu tzw. „buntu dorastania”, czyli negacji, oporu i sprzeciwu wobec zastanych metod postępowania oraz systemu wartości i znaczeń, które w efekcie prowadzą do wyeksponowania wlasnej odrębności, inności i tożsamości ${ }^{12}$. Istotą okresu dorastania jest trudny i skomplikowany proces budowania się tożsamości młodej jednostki, która dąży do poczucia ciagglości w czasie i do uniezależnienia się od sytuacji i okoliczności, chce uzyskać poczucie wewnętrznej spójności i odrębności, ma wizję wlasnej osoby i sama chce decydować o wlasnym losie, odrzucajace,sterowanie" z zewnatrz ${ }^{13}$. A. Galdowa zaznacza, że rozwój tożsamości obejmuje uczucia, wartości, wyobrażenia dotyczace własnej osoby, jej oceny pozytywne i negatywne, stosunek do siebie samego i nastawienie do innych ludzi, do kultury i tradycji, do religii i moralności ${ }^{14}$, a także wyjaśnianie i interpretowanie świata społecznego, w którym żyje rozwijająca się jednostka. Wlaściwie przebiegający proces dorastania jednostki, ksztaltowania się jej tożsamości i integracji osobowości, daje jej (jednostce) poczucie własnej wartości i akceptacji w otoczeniu społecznym doroslych i rówieśników, eliminując zarazem możliwy kryzys tożsamości.

Okres dorastania wywohuje zmiany w każdej sferze osobniczego życia mlodej jednostki, a zmiany te są również zauważalne w jej świadomości i praktykach religijnych oraz $\mathrm{w}$ nastawieniu do autorytetów oficjalnych - religijnych i świeckich. Religijna świadomość, wyrażajacca się w postawach i zachowaniach oraz w stosunku do instytucji religijnych, jest problemem, którym zajmuję się we wlasnych badaniach socjologicznych poświęconych świadomości religijnej i kościelnej młodzieży gimnazjalnej z początku XXI wieku. W szczególności zaś interesuje mnie problem zależności między zmianami zachodzacymi w osobowości gimnazjalistów, glównymi cechami etapu ich rozwoju osobowego, jako zmienną niezależna, a poziomem ich religijności. Problem ten można ujać $\mathrm{w}$ formie pytania: czym specyficznym odznacza się religijność mlodzieży gimnazjalnej, w porównaniu z religijnością innych kategorii mlodzieży? Czy problemy

${ }^{11}$ E. H. E ri k s o n: Tożsamość a cykl życia. Poznań 2004 s. 85-90.

${ }^{12}$ Zob. A. O les z k ow i c z: Bunt dorastania - jego mechanizmy i funkcje. „Psychologia Wychowawcza". R. 1996 nr 5 s. 394-400.

${ }^{13}$ Zob. H. M a m z e r: Tożsamość w podróży. Wielokulturowość a ksztaltowanie tożsamości jednostki. Poznań 2003 s. 48-50.

${ }^{14}$ Zob. A. G a ł d o w a (red.): Tożsamośćc czlowieka. Kraków 2000 s. 9-10. 
pojawiające się w osobowości gimnazjalistów, wskutek zmian w jej strukturze, oddziałują na ich wierzenia i praktyki religijne? Czy gimnazjaliści sami umieja odnaleźć własne miejsce w strukturach kościelnych i uczestniczyć w ich codziennym życiu? Pytania te pozwalają na sformulowanie kilku hipotez empirycznych, które zostaną zweryfikowane na materiale badawczym dotyczącym świadomości religijnej i udziału gimnazjalistów w praktykach religijnych. Hipoteza glówna zaklada, że religijność gimnazjalistów ujawnia cechy i poziomy adekwatne do typowych zmian w strukturze i funkcjonowaniu ich osobowości. Hipoteza druga, z kolei, przyjmuje, że kryzys tożsamości osobowej gimnazjalistów nie pozostaje obojętny dla religijności każdego z nich, a wręcz przeciwnie, oddziałuje częściej negatywnie niż pozytywnie na ich wierzenia i praktyki religijne. Hipoteza trzecia zakłada, że większość gimnazjalistów nie odczuwa potrzeby uczestniczenia w życiu wlasnych wspólnot parafialnych, nie zabiega o więzi z księżmi, a wręcz przeciwnie, izoluje się i unika tych styczności.

Hipotezy te poddam procesowi weryfikacji w dalszej części artykulu, opierajạc się na wynikach wlasnych badań socjologicznych, które zrealizowałem wśród dobranej grupy gimnazjalistów na wsi i w mieście. Chcę zarazem podkreślić, iż w porównaniu z innymi grupami mlodzieży polskiej, świadomość religijna gimnazjalistów rzadko była uwzględniana $w$ badaniach socjologicznych. $Z$ tego względu wyników moich badań nie będę mógł porównywać zbyt często $\mathrm{z}$ analogicznymi wynikami badań innych autorów ${ }^{15}$. Natomiast liczniejsze sa badania nad kryzysami mlodzieży w wieku dorastania, w tym na etapie wczesnej adolescencji ${ }^{16}$.

Badania tu prezentowane wykonalem w ramach problematyki wlasnego seminarium doktorskiego, które prowadziłem na Wydziale PedagogicznoArtystycznym UAM w Kaliszu, oraz w ramach seminarium dyplomowego, które prowadziłem w Instytucie Zarządzania Państwowej Wyższej Szkoly Zawodowej w Kaliszu, przy wydatnej wspólpracy moich seminarzystów i doktorantów, w latach 2001-2004. Badaniami objąłem uczniów w czterech gimnazjach wiejskich i w czterech gimnazjach miejskich w Kaliszu, dobranych techniką losowocelową z list ewidencyjnych uczniów. Łacznie w badaniach tych uczestniczyło 955 osób, w tym 369 w gimnazjach wiejskich $(38,6 \%)$ i 586 w gimnazjach miejskich $(61,4 \%)$. W badanej zbiorowości znajdowało się 636 dziewcząt $(66,6 \%)$ i 319 chlopców $(33,4 \%)$. Uczniowie badani reprezentowali wszystkie trzy klasy szkolne: I - 289, II - 308, III - 358, stanowiąc odpowiednio odsetki: 30,3\%,

${ }^{15}$ Zob. E. S i k o r a: Aspiracje życiowe mlodzieży z osiedli bylych PGR (na przykladzie województwa warmińsko-mazurskiego). Olsztyn 2004 (praca doktorska niepublikowana); T. P o t k a j: Jak zmienia się religijność polskiej mlodzieży?. „Tygodnik Powszechny”. R. 2002 nr 51-52 s. 13.

${ }^{16}$ Zob. E. W y s o c k a: Doświadczenie kryzysu w wartościowaniu a religijność mlodzieży szkót średnich, art. cyt., s. 49-69. 
$32,2 \%$ i 37,5\% ogólu zbiorowości. Badania zostały zrealizowane technika ankiety audytoryjnej w klasach szkolnych, przewidzianej w metodzie sondażu diagnostycznego, którą zastosowalem na tym etapie badań. Z kolei na etapie analizy wyników badań socjologicznych zastosowalem metody statystyczne indeksu zjawisk religijnych (na przykład praktyk religijnych) oraz miernik Q Kendala, stosowany do badania korelacji rangowej między zmiennymi. Miernik ten można stosować wyłącznie do tablic $2 \times 2$. Istotna statystycznie zależność występuje w przypadku, kiedy $\mathrm{Q}=+<0,200-0,999$ albo $\mathrm{Q}=->0,200-0,999$. W przedziale od $-0,200$ do $+0,200$ brak istotnej zależności statystycznej ${ }^{17}$. Miernik Q Kendala jest także określany w statystyce jako wspólczynnik zbieżności Yule’a. Warunkiem jego zastosowania $\mathrm{w}$ obliczeniach jest uprzednie skonstruowanie, wspomnianej już wyżej, tabeli 2x2 (dwuelementowej) ${ }^{18}$.

\section{Kryzys tożsamości a potrzeba akceptacji u gimnazjalistów}

Janusz Mariański, omawiając uwarunkowania życia dzisiejszej młodzieży polskiej, stwierdza jednoznacznie, że znaczny jej odsetek znajduje się w trudnej sytuacji dysonansowo-stresowej, która wynika między innymi z braku zgodności pomiędzy systemem wartości uznawanych przez mlodzież za ważne, a systemem aksjologicznym wynikającym $z$ religii katolickiej i z jej moralności. Autor twierdzi, że dyssens pomiędzy wartościami upowszechnianymi w spoleczeństwie, a wartościami związanymi $\mathrm{z}$ religią katolicką przybiera obecnie zmienne rozmiary i zaklóca system znaczeń licznych jednostek i zbiorowości, a szczególnie na jego oddzialywanie są narażeni ludzie młodzi, dopiero zapoznający się z zasadami obowiazującymi w życiu spolecznym - świeckim i religijnym. W efekcie tego wplywu dochodzi często do ostrych napięć między indywidualną wolnościa, a oficjalnymi zobowiązaniami normatywnymi. Napięcia te, z kolei, redefiniują rolę ,znaczących innych", jako dotąd akceptowanych autorytetów w ocenach osób mlodych, a także wywohują kryzys ich tożsamości ${ }^{19}$. Starsi ludzie, jako autorytety czy „znaczący inni”, jeżeli rzeczywiście chca ułatwić warunki życia młodzieży, winni szerzej i częściej przekazywać jej „ster” budowania „,nowego" świata, gdyż inaczej świat ten zostanie zakwestionowany i odrzucony,

${ }^{17}$ Zob. H.M. B l a 1 o c k: Statystyka dla socjologów. Warszawa 1975 s. 260; J. L u t y ń s k i: Propozycja nowej miary sily zależności między dwiema zmiennymi w socjologii. Warszawa $1968 \mathrm{~s}$. 264.

${ }^{18}$ Zob. J. P o c i e c h a: O zastosowaniu wspólczynnika zależności stochastycznej. W: K. Z a j a c (red.): Problemy statystyczne i demograficzne. Wroclaw-Gdańsk 1974 s. 67.

${ }^{19} \mathrm{~J}$. Mari a ń s ki: Kościól a religijność mlodzieży. W: I. B or ow ik, W. Z d a n i ew i c z (red.): Od Kościola ludu do Kościola wyboru. Religia a przemiany spoleczne w Polsce. Kraków 1996 s. 120-122; zob. A. G ó r n y: Znaczacy inni. Socjalizacja religinna i moralna mlodziezy. Szkic socjologiczny na przykladzie województwa ślaskiego. W: J. B a n i a k (red.): Religijna i moralna kondycja mlodzieży polskiej - mity i rzeczywistość. „Socjologia Religii”. R. 2005: 3 s. 265-290. 
jako „obcy” i „nieswój”, gdyż kiedyś wymyślony, a dziś usilnie podtrzymywany przez starsze pokolenie, co dotyczy wszystkich sfer, w tym religijnej, tego świata. Do struktur tego „starego" i „obcego" świata mlodzież wlącza i wlicza również Kościól i system jego wartości, zarówno symbolicznych, jak i mających wymiar konkretny.

Problem ten uwzględnilem także we wlasnych badaniach socjologicznych, chcac zorientować się w skali i poziomie kryzysu tożsamości gimnazjalistów polskich, a także w tym, czy kryzys ten ma związek $\mathrm{z}$ ich religijnością. Tabela 1 ukaże skalę i przejawy kryzysu tożsamości moich respondentów.

Tabela 1. Poczucie i przejawy kryzysu toźsamości u badanych gimnazjalistów

\begin{tabular}{|c|c|c|c|c|c|c|c|c|c|c|}
\hline \multirow{2}{*}{$\begin{array}{l}\text { Respondenci } \\
\text { Kryzys tożsa- } \\
\text { mości }\end{array}$} & \multicolumn{2}{|c|}{ Kobiety } & \multicolumn{2}{|c|}{ Mężczyźni } & \multicolumn{2}{|c|}{ Gim. wiejskie } & \multicolumn{2}{|c|}{ Gim. miejskie } & \multicolumn{2}{|c|}{ Razem } \\
\hline & $\mathrm{L}$. & $\%$ & $\mathrm{~L}$. & $\%$ & $\mathrm{~L}$. & $\%$ & $\mathrm{~L}$. & $\%$ & $\mathrm{~L}$. & $\%$ \\
\hline \multicolumn{11}{|l|}{ Skala kryzysu: } \\
\hline Bardzo silny & 234 & 36,8 & 104 & 32,6 & 104 & 28,2 & 222 & 37,9 & 326 & 21,6 \\
\hline Silny & 102 & 16,0 & 92 & 28,8 & 78 & 21,1 & 128 & 21,8 & 206 & 34,0 \\
\hline Umiarkowany & 125 & 19,6 & 60 & 18,8 & 66 & 17,9 & 119 & 20,3 & 185 & 19,4 \\
\hline Brak kryzysu & 147 & 23,2 & 43 & 13,5 & 93 & 26,6 & 92 & 15,7 & 190 & 20,0 \\
\hline Brak wskazania & 28 & 4,4 & 20 & 6,3 & 23 & 6,2 & 25 & 4,3 & 48 & 5,0 \\
\hline \multicolumn{11}{|l|}{ Przejawy kryzysu: } \\
\hline Zagubienie & 445 & 70,0 & 205 & 64,3 & 266 & 72,1 & 384 & 65,5 & 650 & 68,1 \\
\hline Wyobcowanie & 392 & 61,6 & 194 & 60,8 & 258 & 69,9 & 328 & 56,0 & 586 & 61,4 \\
\hline $\begin{array}{l}\text { Kompleks } \\
\text { wartości }\end{array}$ & 385 & 60,5 & 166 & 52,0 & 237 & 64,2 & 314 & 53,6 & 551 & 57,7 \\
\hline $\begin{array}{l}\text { Agresja i } \\
\text { zawiść }\end{array}$ & 317 & 49,8 & 188 & 58,9 & 163 & 44,2 & 342 & 58,4 & 505 & 52,9 \\
\hline $\begin{array}{l}\text { Brak pewności } \\
\text { siebie }\end{array}$ & 408 & 64,1 & 177 & 55,5 & 276 & 74,8 & 309 & 52,7 & 585 & 61,3 \\
\hline Konfliktowość & 283 & 44,5 & 123 & 38,6 & 148 & 40,1 & 258 & 44,0 & 406 & 42,5 \\
\hline Bunt i sprzeciw & 427 & 67,1 & 247 & 77,4 & 235 & 63,7 & 439 & 74,9 & 674 & 70,6 \\
\hline $\begin{array}{l}\text { Utrata sensu } \\
\text { życia }\end{array}$ & 213 & 33,5 & 132 & 41,4 & 138 & 37,4 & 207 & 35,3 & 345 & 36,1 \\
\hline Brak wskazania & 32 & 5,0 & 24 & 7,5 & 25 & 6,8 & 31 & 5,3 & 56 & 5,9 \\
\hline Ogółem & 636 & 100,0 & 319 & 100,0 & 369 & 100,0 & 586 & 100,0 & 955 & 100,0 \\
\hline
\end{tabular}

Dominujący odsetek badanych gimnazjalistów przeżywa kryzys wlasnej tożsamości, który ma charakter egzystencjalny i powoduje w dość licznych przypadkach (okolo 58\%) dezintegrację ich osobowości i trudności w odnajdowaniu się w społecznej rzeczywistości, w tym również we własnym środowisku rówieśniczym, przy czym „zaburzeniu” ulegają najczęściej i najsilniej relacje w sferze plci - między dorastającymi wolniej chlopcami i dojrzewajacymi szybciej dziewczętami. Ponad 1/5 badanych ma poczucie „bardzo silnego” kryzysu, a 1/3 „,silnego", zaś niespelna $1 / 5$ mówila o „umiarkowanym” kryzysie swojej tożsamości. O braku takiego kryzysu wspominala jedynie $1 / 5$ badanych gimnazjalistów, którzy sami stwierdzali, że nie zauważaja „niczego zlego" lub „istotnych zmian” w rozwoju swojej osobowości, że osobowość ich jest nadal zintegrowana, a oni funkcjonują „,bez przeszkód” na co dzień i skutecznie realizują swoje plany egzystencjalne. Natomiast $4 / 5$ przeżywa „silny” lub „słaby” kryzys swojej tożsamo- 
ści, który utrudnia im w różnym stopniu normalne funkcjonowanie i wykonywanie zadań ważnych na tym etapie ich rozwoju.

Kryzys tożsamości przeżywany przez większość gimnazjalistów objawia się, w zależności od plci, wieku i miejsca zamieszkania, w różnych formach i postaciach (zob. tabela 1). W ukladzie rangowym na trzech kolejnych miejscach przejawy kryzysu są następujące: 1 - „,bunt i sprzeciw” wobec zastanej rzeczywistości (70,6\%); 2 - „zagubienie” $(68,1 \%) ; 3$ - „wyobcowanie” $(61,4 \%)$. Pozostale przejawy wskazaly już mniejsze odsetki respondentów, od $61,3 \%$ do $36,1 \%$ wyborów.

Poziom kryzysu tożsamości badanych gimnazjalistów można precyzyjniej ukazać i poprawniej zinterpretować, jeśli poslużymy się tabelą korelacji zmiennych ${ }^{20}$, w której poziom ten uprościmy do dwóch kategorii: „większy” (którego podstawą sa dane dotyczące skali „bardzo silny”) i „mniejszy” (który u swoich podstaw ma skale ,silny" i „umiarkowany”), a następnie poziomy te skonfrontujemy z niektórymi cechami respondentów, jako zmiennymi niezależnymi, jak: pleć, miejsce zamieszkania, rodzaj szkoly, pochodzenie spoleczne. Iloraz „mniej” do ,więcej” precyzyjnie ujawni zarówno stopień świadomości kryzysowej badanych, jak i poziom samego kryzysu tożsamości dla kolejnych grup respondentów, przy uwzględnieniu ich cech. Konstrukcja tabeli korelacyjnej zostala w taki sposób zbudowana, że im mniejszy iloraz, tym większa świadomość kryzysu tożsamości i wyższy poziom tegoż kryzysu. Iloraz uzyskany można uznać za liczbę przeciętną dla calego zbioru danych. J. Wojtyniak zaznacza, iż Jednym z najpopularniejszych narzędzi analizy sq przeciętne. Określajq one - pod względem jakiejśs cechy - calq zbiorowość za pomocq jednej wielkości, dajqc w ten sposób charakterystykę latwo uchwytna, przejrzysta i nadajaca się do porów$n a h^{21}$. Iloraz średni, uzyskany w obliczeniach, zezwala na wyszukanie tych respondentów, którzy ujawniają albo „wyższy” poziom kryzysu od „,przeciętnego”, albo też „niższy” poziom, lokując się w "lepszej” świadomości tego kryzysu. Korelacje te zilustruje tabela 2, uwzględniając wskazane cechy respondentów.

Tabela 2. Korelacja świadomości i poziomu kryzysu tożsamości z cechami badanych

\begin{tabular}{|c|c|c|c|c|}
\hline \multirow{3}{*}{ Kategorie zmiennych } & \multirow{3}{*}{$\mathrm{N}=100 \%$} & \multicolumn{2}{|c|}{ Poziom świadomości kryzysu } & \multirow{3}{*}{$\begin{array}{l}\text { Iloraz: } \\
\text { mniej-więcej }\end{array}$} \\
\hline & & „mniejszy" & „większy" & \\
\hline & & \multicolumn{2}{|c|}{ w odsetkach } & \\
\hline Ogółem & 717 & 54,5 & 45,5 & 1,20 \\
\hline \multicolumn{5}{|l|}{ Pleć: } \\
\hline Dziewczęta & 461 & 50,7 & 49.3 & 1,02 \\
\hline Chtopcy & 256 & 64,1 & 35,9 & 1,78 \\
\hline \multicolumn{5}{|l|}{ Wiek: } \\
\hline $14-15$ & 334 & 56,4 & 43,6 & 1,29 \\
\hline $16-17$ & 383 & 59,2 & 40,8 & 1.45 \\
\hline
\end{tabular}

${ }^{20}$ Zob. Z. R o g o z i ń s k i: Z metodyki statystycznej badań spolecznych. Łódź 1955 s. 52-53.

${ }^{21}$ J. W o j t y n i a k: Zasady statystyki. Warszawa 1956 s. 130-131. 


\begin{tabular}{|l|c|c|c|c|}
\hline Rodzaj gimnazjum: & 248 & 58,1 & 41,9 & 1,58 \\
\hline Wiejskie & 469 & 52,7 & 47,3 & 11,1 \\
\hline Miejskie & \multicolumn{5}{|l|}{} \\
\hline Pochodzenie społeczne: & 188 & 69,4 & 39,6 & 1,52 \\
\hline Chłopskie & 205 & 57,6 & 42,4 & 1,35 \\
\hline Robotnicze & 93 & 58,4 & 41,6 & 1,40 \\
\hline Rzemieślnicze & 176 & 51,1 & 48,9 & 1,04 \\
\hline Inteligenckie & 55 & 56,8 & 43,2 & 1,31 \\
\hline Mieszane & \multicolumn{5}{|l|}{} \\
\hline Typ rodziny: & 567 & 53,4 & 46,6 & 1,14 \\
\hline Pełna (zintegrowana) & 107 & 61,9 & 38,1 & 1,62 \\
\hline Rozbita (rozwód) & 43 & 54,2 & 45,8 & 1,18 \\
\hline Samotny rodzic & \multicolumn{5}{|l|}{} \\
\hline Miejsce zamieszkania: & 248 & 58,1 & 41,9 & 1,58 \\
\hline Wieś & 186 & 60,3 & 39,7 & 1,51 \\
\hline Małe miasto & 283 & 57,5 & 42,5 & 1,35 \\
\hline Duże miasto &
\end{tabular}

Podstawą analizy wskaźników ujętych w tabeli korelacyjnej jest ustalony iloraz poziomu świadomości kryzysu tożsamości gimnazjalistów. Przypomnijmy, że im mniejszy jest iloraz, tym większa jest świadomość kryzysu i sam jego poziom u badanych osób. Iloraz ten, czyli liczbę 1,20, można przyjąć jako „,przeciętny" wskaźnik dla ogólu badanych gimnazjalistów (zbiorowości, populacji). Wprawdzie ustalony iloraz $(1,20)$ ilustruje „mniejsza” świadomość i „niższy” poziom kryzysu tożsamości badanych osób, jednak można, wzorując się na nim, odnaleźć wśród całości respondentów te jednostki, które lokuja się zarówno poniżej, jak i te, które znajdują się powyżej przeciętnej ilorazu. Zmienne, które znajdują się powyżej wskaźnika 1,20, lokujemy w sferze czy strefie „gorszej” świadomości i „większego" poziomu kryzysu tożsamości. Z kolei zmienne z liczbą poniżej wskaźnika 1,20 umieszczamy w sferze „lepszej” świadomości i „mniejszego" poziomu kryzysu tożsamości badanych uczniów gimnazjów wiejskich i miejskich. W świetle tych ustaleń widzimy, że silniejszy kryzys (wyższy jego poziom) ujawniaja chlopcy $(1,78)$, a zarazem oni maja gorszą jego świadomość, lokując się powyżej wskaźnika przeciętnego. Kryzys ów jest slabszy u dziewcząt, gdyż lokuje się poniżej wskaźnika przeciętnego. Kryzys ten jest zjawiskiem silniejszym i częstszym wśród gimnazjalistów wiejskich $(1,58)$ niż miejskich $(1,11)$, u nich też występuje gorsza świadomość jego istoty i skutków. Typ rodziny i jej spójność także mają związek z poziomem i świadomością kryzysu tożsamości dzieci na tym etapie rozwoju. W rodzinach pelnych i zintegrowanych jest on najmniejszy $(1,14)$, poniżej średniej, a w rodzinach rozbitych jest największy $(1,62)$, powyżej przeciętnej. Dzieci wiejskie przeżywają kryzys tożsamości silniej $(1,58)$ niż dzieci z malych $(1,51)$ i dużych miast $(1,35)$, zwlaszcza te, które migruja po naukę szkolną do gimnazjów miejskich. Wskaźnik kryzysu gimnazjalistów wiejskich $(1,58)$ jest niemal identyczny (pokrywa się) ze wskaźnikiem kryzysu uczniów rodowodu chlopskiego $(1,52)$. Najniższy poziom kryzysu $(1,04)$, czyli poniżej przeciętnej, dostrzegłem u gimnazjalistów, którzy pochodza $\mathrm{z}$ rodzin i środowisk inteligenckich. Uczniowie ci sami wskazywali na znacznie korzystniejsze, niż ich koledzy z innych grup społecznych, warunki 
rozwoju i metody pomocy w rozwiąywaniu trudności prowadzacych wprost do kryzysu tożsamości we własnych rodzinach i środowiskach.

W hipotezie empirycznej przyjąlem, iż kryzys tożsamości jednostki mlodej, szczególnie jego wysoki poziom i niska świadomość, mają ujemny wplyw na jej świadomość i udzial w praktykach religijnych. Im poziom kryzysu jest wyższy, a świadomość jego niższa u jednostki, tym niższa jest jej świadomość religijna i slabsza aktywność kultowa, czyli slabszy jest jej udzial w praktykach religijnych. Wyniki badań potwierdzily trafność tej hipotezy.

\section{Deklaracje wierzeń i praktyk religijnych gimnazjalistów}

W przekonaniu S. Zaręby Wiara religijna stanowi dla większości wspólczesnej mlodzieży istotny element systemu wartości. Pozytywny w większości stosunek do wiary i jej komponentów wyraża się w sposobach manifestowania i konkretyzowania tychże wartosici w spolecznych i prywatnych zachowaniach religij$n y c h^{22}$. Bez watpienia, deklaracje wiary i praktyk religijnych stanowią fundament żywotności religijnej jednostki na każdym etapie jej życia. We wlasnych badaniach kwestię tę uwzględniłem i prosiłem gimnazjalistów o określenie poziomu wlasnej wiary religijnej, wedlug kategorii stosowanych w badaniach socjologicznych, oddających faktyczne poziomy świadomości religijnej katolików.

\section{Deklaracje wiary religijnej podane przez gimnazjalistów}

W tabeli 3 zaprezentuję wskaźniki deklaracji globalnych wyznań wiary badanych gimnazjalistów, biorąc pod uwagę ich płeć i typ gimnazjum, w którym się uczą.

Tabela 3. Autodeklaracje wiary religijnej badanych gimnazjalistów

\begin{tabular}{|l|c|c|c|c|c|c|c|c|c|c|}
\hline \multirow{2}{*}{$\begin{array}{l}\text { Respondenci } \\
\text { Poziom wiary }\end{array}$} & \multicolumn{2}{|c|}{ Kobiety } & \multicolumn{2}{|c|}{ Mężczyźni } & \multicolumn{2}{c|}{ Gim. wiejskie } & \multicolumn{2}{|c|}{ Gim. miejskie } & \multicolumn{3}{c|}{ Razem } \\
\cline { 2 - 13 } & L. & $\%$ & L. & $\%$ & L. & $\%$ & L. & $\%$ & L. & $\%$ \\
\hline Glęboko wierzący & $\begin{array}{c}11 \\
8\end{array}$ & 18,6 & 53 & 16,6 & 80 & 21,7 & 91 & 15,5 & 171 & 17,9 \\
\hline Wierzacy w normie & $\begin{array}{c}40 \\
6\end{array}$ & 63,8 & $\begin{array}{c}17 \\
2\end{array}$ & 54,0 & 213 & 57,8 & 365 & 62,3 & 578 & 60,5 \\
\hline Wątpiący religijnie & 48 & 7,6 & 37 & 11,6 & 32 & 8,7 & 53 & 9,0 & 85 & 8,9 \\
\hline Obojętny religijnie & 34 & 5,3 & 22 & 6,9 & 19 & 5,1 & 37 & 6,3 & 56 & 5,9 \\
\hline Niewierzacy & 18 & 2,8 & 19 & 5,9 & 14 & 3,7 & 23 & 4,0 & 37 & 3,9 \\
\hline Brak danych & 12 & 1,9 & 16 & 5,0 & 11 & 3,0 & 17 & 2,9 & 28 & 2,9 \\
\hline Ogółem & 63 & 100,0 & 31 & 100,0 & 369 & 100,0 & 586 & 100,0 & 955 & 100,0 \\
\hline
\end{tabular}

${ }^{22} \mathrm{~S}$. Z a r ę b a: Dynamika świadomości religijno-moralnej mlodzieży $w$ warunkach przemian ustrojowych w Polsce (1988-1998). Warszawa 2003 s. 123. 
Ponad $3 / 4$ badanych gimnazjalistów stwierdzily, że są osobami wierzacymi w Boga wedlug zasad religii rzymskokatolickiej, a w tej grupie 17,9\% uznaje siebie za osoby „głęboko" wierzace, zaś pozostali $(60,5 \%)$ wierzą „w normie”, czyli bez specjalnego zaangażowania we wszystkie zalecenia i normy religii i Kościola. Pozostaly odsetek respondentów $(18,7 \%)$ zgłasza różne trudności w swojej wierze religijnej, a wśród nich niespełna $4 \%$ stwierdziło, iż sa „,niewierzący”. W tej grupie (z klopotami w wierze) największy odsetek stanowią osoby wahające się z akceptacja zasad wiary katolickiej $(8,9 \%)$, a mniej już jest obojętnych religijnie $(5,9 \%)$. Dziewczęta są bardziej religijne niż chłopcy, zarówno w najwyższym poziomie wiary (o 2,0\%), jak i w poziomie podstawowym (o 9,8\%). Lacznie ,staly" poziom wiary religijnej deklaruje $82,4 \%$ dziewcząt i $70,6 \%$ chlopców, a także $79,5 \%$ gimnazjalistów wiejskich i 77,8\% miejskich. Lacznie problemy z wiara religijną ma $15,7 \%$ dziewcząt i $24,4 \%$ chłopców oraz $17,5 \%$ gimnazjalistów wiejskich i $19,3 \%$ miejskich ${ }^{23}$.

W badaniach interesowałem się także samooceną poziomu wlasnej wiary religijnej wśród gimnazjalistów, dając im do wyboru trzy kategorie oceny tegoż poziomu: wysoki (5-8 punktów), średni (4), niski (1-3). Skalę tej oceny ukaże tabela zbiorcza 4.

Tabela 4. Samoocena wiary religijnej dokonana przez gimnazjalistów

\begin{tabular}{|c|c|c|c|c|c|c|c|c|c|c|}
\hline \multirow{2}{*}{$\begin{array}{l}\text { Respondenci } \\
\text { Poziom wiary }\end{array}$} & \multicolumn{2}{|c|}{ Kobiety } & \multicolumn{2}{|c|}{ Mężczyźni } & \multicolumn{2}{|c|}{ Gim. wiejskie } & \multicolumn{2}{|c|}{ Gim. miejskie } & \multicolumn{2}{|c|}{ Razem } \\
\hline & L. & $\%$ & $\mathrm{~L}$. & $\%$ & $\mathrm{~L}$. & $\%$ & L. & $\%$ & $\mathrm{~L}$. & $\%$ \\
\hline Wysoki (W) & 323 & 50,8 & 123 & 38,6 & 190 & 51,5 & 256 & 43,7 & 446 & 46,7 \\
\hline Średni (S) & 156 & 24,4 & 95 & 29,8 & 93 & 25,2 & 158 & 27,0 & 251 & 26,3 \\
\hline Niski (N) & 143 & 22,5 & 84 & 26,3 & 75 & 20,3 & 152 & 25,9 & 227 & 23,8 \\
\hline Brak danych & 14 & 2,2 & 17 & 5,3 & 11 & 3,0 & 34 & 3,4 & 31 & 3,2 \\
\hline Ogólem & 636 & 100,0 & 319 & 100,0 & 369 & 100,0 & 586 & 100,0 & 955 & 100,0 \\
\hline
\end{tabular}

Badani gimnazjaliści dość krytycznie odnieśli się do jakości swojej wiary religijnej, czy też ocenili poziom zmian w niej wedlug przyjętej skali. Niespelna $1 / 2$ badanych deklaruje „wysoki" poziom swojej wiary w Boga, a dominuja tu dziewczęta nad chłopcami (o 12,2\%), a także uczniowie z gimnazjów wiejskich nad swoimi kolegami i koleżankami z gimnazjów miejskich (o 7,8\%). Jednocześnie aż 50,1\% badanych gimnazjalistów krytycznie ocenia poziom swojej wiary, lokując go albo na poziomie „średnim" (26,3\%), albo na poziomie „niskim” $(23,8 \%)$. To niezadowolenie widzimy zarówno u $47 \%$ dziewcząt i u $56,1 \%$

${ }^{23}$ Zob. E. W y s o c k a, art. cyt., s. 54. (Badana przez autorkę młodzież szkól średnich deklarowała następujace poziomy swojej wiary: głęboko wierzący $-18,8 \%$, wierzący $-62,4 \%$, wahajacy się $-10,4 \%$, obojętni religijnie $-5,9 \%$, niewierzący $-2,5 \%$; por. A. Górny, art. cyt., s. 269 , tabela 1. (Autor informuje, że jego młodzi respondenci deklarują następujące poziomy wiary w Boga: głęboko - $14,7 \%$, w normie $-76,8 \%$, obojętny $-7,4 \%$, niewierzący $-0,9 \%$, przeciwnik religii $-0,1 \%$ ) 
chlopców, jak i u 45,5\% uczniów gimnazjów wiejskich i u 52,9\% uczniów gimnazjów miejskich

Krytyczne nastawienie respondentów do wlasnej wiary religijnej ukazuje również różnica między poziomem „wysokim" i poziomem, niskim” (W : N). W lącznym ujęciu różnica ta wynosi 1,96 , a w polaczeniu ze zmiennymi ksztaltuje się jeszcze inaczej: w korelacji z plcią respondentów stanowi dla dziewcząt 2,25 i dla chłopców 1,46 oraz dla uczniów szkól wiejskich 2,53 i uczniów szkól miejskich 1,68. Średnia ocena zadowolenia z wlasnej religijności u dziewcząt jest wyższa od oceny ogólnej w calej badanej zbiorowości o 0,29 , natomiast u chlopców jest ona niższa o 0,5 . Uczniowie szkół wiejskich optymistyczniej ocenili swoją wiarę religijną niż wszyscy badani (o 0,57$)$, natomiast ocena uczniów szkól miejskich jest gorsza $(\mathrm{o} 0,28)^{24}$.

\section{Praktyki religijne spelniane przez gimnazjalistów}

W ocenie socjologów religii, praktyki religijne należą do najbardziej podstawowych skladników religijności tradycyjnej i ciaggle są dość licznie realizowane przez katolików, zarówno doroslych, jak i mlodych, zaś w Polsce są one nadal główną cechą religijności ludowej i kościelnej ${ }^{25}$. Badacze religijności coraz częściej uwzględniaja w swoich planach i koncepcjach praktyki religijne mlodzieży z różnych kategorii, choć najliczniejsze opracowania dotyczą młodzieży szkolnej i akademickiej. Wielu socjologów interesuje się zarówno strukturą jak i dynamiką religijności młodzieży, ukazując je z wielu punktów widzenia, i w wielu kontekstach. W religijnym życiu mlodzieży dostrzegają oni „przyszlość” religijnych struktur Kościoła katolickiego ${ }^{26}$. Uczestniczenie mlodzieży w praktykach religijnych, zwlaszcza w obowiazkowych, oznacza jej przynależność i więź z Kościołem i z wspólnotą parafialną ${ }^{27}$. Z kolei sama parafia „odnajduje” w tych praktykach wlasną tożsamość religijną ${ }^{28}$. Między tożsamością religijną jednostek, a tożsamością religijną parafii zachodzi istotna zależność.

${ }^{24}$ Por. E. W y s o c k a, art. cyt., s. 54, tabl. 1. (Respondenci autorki własną wiarę ocenili wedlug następującej skali: poziom niski $-21,29 \%$, średni $-24,75 \%$, wysoki $-51,96 \%$, a stosunek między poziomami skrajnymi (W : N); wynosi tu 2,53); zob. J. M a ri a ń s ki: Religijność mlodzieży polskiej wobec wyzwań re-ewangelizacji Europy. W: W. N o w a k (red.): Mlodzież a ewangelizacja w perspektywie wyzwań XXI wieku. Olsztyn 2000 s. 14-15.

${ }^{25}$ Zob. J. B a n i a k: Praktyki religijne katolików XX wieku (analiza socjologiczna). „Studia Gnesnensia". R. 2002: 16 s. 277-318; W. P i wo w a r sk i (red.): Religijność ludowa-ciaglość $i$ zmiana. Wroclaw 1983 s. 5-12.

${ }^{26}$ Zob. S. Z a rę ba: Dynamika świadomości religijno-moralnej mlodzieży w warunkach przemian ustrojowych $w$ Polsce (1988-1998). Warszawa 2003

${ }^{27}$ Zob. G. L e B r a s: L'Eglise et le vilage. Paris 1976 s. 167-168.

${ }^{28}$ Zob. N. Gre in a c he r: Soziologische Aspekte des Selbstvollzugs der Kirche. W: Handbuch der Pastoraltheologie. T. 1. Freiburg im Breisgau 1964 s. 439-440. 
W dalszej analizie wyników badań uwagę skoncentruję na udziale gimnazjalistów w czterech praktykach religijnych: w mszy niedzielnej, spowiedzi, Komunii, modlitwie indywidualnej. Wskaźniki tych praktyk ukażę w kolejnych tabelach zbiorczych.

\section{Udzial gimnazjalistów w obowiązkowej mszy niedzielnej}

Jak ksztaltują się wskaźniki udzialu respondentów w obowiązkowej mszy niedzielnej w świetle ich wlasnych deklaracji? Deklaracje ich ukaże tabela 5.

Największy odsetek badanych gimnazjalistów uczestniczy systematycznie w mszy niedzielnej, czyli udaje się do kościola regularnie w każdą niedzielę $(52,3 \%)$. $Z$ kolei $23,5 \%$ uczestniczy niesystematycznie, czyli albo kilka razy w miesiacu $(15,2 \%)$, albo tylko jeden raz w miesiacu $8,3 \%$ ). Ponadto, $6,7 \%$ uczestniczy okazjonalnie, pod presją różnych czynników i powodów. Łącznie w calej badanej zbiorowości gimnazjalistów $82,5 \%$ uczestniczy w mszy niedzielnej, w tym 52,3\% regularnie w każdą niedzielę przyjętego okresu.

Tabela 5. Udzial gimnazjalistów w obowiązkowej mszy niedzielnej

\begin{tabular}{|c|c|c|c|c|c|c|c|c|c|c|}
\hline \multirow{2}{*}{$\begin{array}{l}\text { Respondenci } \\
\text { Udział w mszy } \\
\text { św. }\end{array}$} & \multicolumn{2}{|c|}{ Kobiety } & \multicolumn{2}{|c|}{ Mężczyźni } & \multicolumn{2}{|c|}{ Gim. wiejskie } & \multicolumn{2}{|c|}{$\begin{array}{l}\text { Gim. miej- } \\
\text { skie }\end{array}$} & \multicolumn{2}{|c|}{ Razem } \\
\hline & $\mathrm{L}$. & $\%$ & $\mathrm{~L}$. & $\%$ & $\mathrm{~L}$. & $\%$ & L. & $\%$ & L. & $\%$ \\
\hline W każdą niedzielę & 338 & 53,2 & 162 & 50,8 & 216 & 58,4 & 284 & 48,5 & 500 & 52,3 \\
\hline $\begin{array}{l}\text { Kilka razy w } \\
\text { miesiącu }\end{array}$ & 116 & 18,3 & 29 & 9,1 & 60 & 16,3 & 85 & 14,5 & 145 & 15,2 \\
\hline Raz w miesiącu & 52 & 8,2 & 27 & 8,5 & 23 & 6,3 & 56 & 9,5 & 79 & 8,3 \\
\hline $\begin{array}{l}\text { Okazjonalnie (1- } \\
\text { 2) }\end{array}$ & 34 & 5,3 & 30 & 9,4 & 23 & 6,3 & 41 & 7,0 & 64 & 6,7 \\
\hline Nie pamiętam & 27 & 4,2 & 19 & 5,9 & 14 & 3,8 & 32 & 5,5 & 46 & 4,8 \\
\hline Nie uczestniczę & 58 & 9,1 & 49 & 15,3 & 28 & 7,6 & 79 & 13,5 & 107 & 11,2 \\
\hline Brak danych & 11 & 1,7 & 3 & 1,0 & 5 & 1,3 & 9 & 1,5 & 14 & 1,5 \\
\hline Ogółem & 636 & 100,0 & 319 & 100,0 & 369 & 100,0 & 586 & 100,0 & 955 & 100,0 \\
\hline
\end{tabular}

W mszy niedzielnej liczniej uczestniczą dziewczęta i uczniowie gimnazjów wiejskich niż chłopcy i gimnazjaliści miejscy, zarówno regularnie, jak i nieregularnie. Jednocześnie zauważamy, że co dziesiąty respondent w ogóle nie uczestniczy w tym obowiązku religijnym. Wskaźniki tej absencji sa odmienne przy uwzględnieniu zmiennych niezależnych: odsetek dziewcząt opuszczających mszę niedzielną jest mniejszy $(9,1 \%)$ niż odsetek chlopców $(15,3 \%)$, a także odsetek gimnazjalistów wiejskich $(7,6 \%)$ niż miejskich $(13,5 \%)$.

W dodatkowym pytaniu prosilem respondentów o ukazanie ewentualnego swojego udziału w mszy w dni robocze, w ciagu tygodnia. Udział w codziennej mszy nie jest podstawowym obowiązkiem religijnym katolika, jednak, jeśli ma on miejsce, świadczy o glębszej jego pobożności i o ściślejszym związku z parafią. Udzial ich w tej mszy ukaże 6 tabela zbiorcza. W analizie biorę pod uwagę osoby, które także uczestniczyly w mszy niedzielnej. Osoby zaniedbujące mszę niedzielną także nie uczestniczyly w niej w dni robocze. 
O ile w obowiązkowej mszy niedzielnej uczestniczy ogólem $82,5 \%$ respondentów ze zmienną częstotliwością, w tym 52,3\% regularnie w każdą niedzielę, o tyle udzial ich w mszy w dni robocze jest zaledwie ,śladowy”, jeśli deklaruje go lącznie, zachowawszy zmienną częstotliwość, 18\% całości. Przyjęte cechy spoleczne nie wprowadzają znaczących różnic między wskaźniki wyrażajace udzial gimnazjalistów w mszy powszedniej. Dziewczęta jedynie nieznacznie liczniej niż chlopcy przychodzą na mszę do kościola parafialnego lub innego (o 1,5\%), podobnie sytuacja ksztaltuje się w uczestnictwie gimnazjalistów wiejskich i miejskich; ci pierwsi uczestniczą liczniej (o 3,5\%) niż ci drudzy.

Tabela 6. Udział gimnazjalistów w mszy w dni robocze

\begin{tabular}{|c|c|c|c|c|c|c|c|c|c|c|}
\hline \multirow{2}{*}{$\begin{array}{l}\text { Respondenci } \\
\text { Msza w dni } \\
\text { robocze }\end{array}$} & \multicolumn{2}{|c|}{ Kobiety } & \multicolumn{2}{|c|}{ Mężczyźni } & \multicolumn{2}{|c|}{ Gim. wiejskie } & \multicolumn{2}{|c|}{ Gim. miejskie } & \multicolumn{2}{|c|}{ Razem } \\
\hline & L. & $\%$ & $\mathrm{~L}$. & $\%$ & L. & $\%$ & $\mathrm{~L}$. & $\%$ & $\mathrm{~L}$. & $\%$ \\
\hline W każdy dzień & 50 & 9,1 & 19 & 7,6 & 35 & 10,7 & 34 & 7,2 & 69 & 8,6 \\
\hline $\begin{array}{l}2-3 \text { razy w } \\
\text { tygodniu }\end{array}$ & 27 & 4,9 & 7 & 2,8 & 23 & 7,0 & 11 & 2,3 & 34 & 4,2 \\
\hline $\begin{array}{l}1 \text { raz w tygo- } \\
\text { dniu }\end{array}$ & 32 & 5,8 & 10 & 4,0 & 23 & 7,0 & 23 & 4,0 & 42 & 5,2 \\
\hline Nie uczestniczę & $\begin{array}{c}42 \\
5\end{array}$ & 77,1 & 204 & 81,3 & 234 & 71,6 & 395 & 83,1 & 629 & 78,5 \\
\hline Brak danych & 17 & 3,1 & 11 & 4,3 & 12 & 3,7 & 16 & 3,4 & 28 & 3,5 \\
\hline Ogółem & $\begin{array}{c}55 \\
1\end{array}$ & 100,0 & 251 & 100,0 & 327 & 100,0 & 475 & 100,0 & 802 & 100,0 \\
\hline
\end{tabular}

Jednocześnie badania wykazaly, że aż 78,5\% gimnazjalistów, w tym liczniej chłopcy (o 4,2\%) i uczniowie ze szkól miejskich (o 11,5\%) w ogóle nie uczestniczyli w mszy w dni robocze, różnie uzasadniając wlasna deklarację. Wskaźnik ten wydaje się rażąco wysoki w zestawieniu z wskaźnikiem braku uczestnictwa respondentów w mszy niedzielnej: ogólem $-11,2 \%$, w tym dziewczęta $-9,1 \%$ i chlopcy $-15,3 \%$ oraz gimnazjaliści wiejscy $-7,6 \%$ i miejscy $-13,5 \%$. Dane te upoważniaja do wniosku, iż dominujący odsetek badanych gimnazjalistów, w tym większy chłopców, odznacza się słaba pobożnościa, skierowana zdecydowanie na „wypelnianie normy”, czyli ograniczają się oni jedynie do uczestnictwa w mszy niedzielnej jako obowiazkowej, w dodatku nie wszyscy spelniają ten obowiązek systematycznie, czyli w każdą niedzielę. Może to oznaczać, iż sprawy religijne nie odgrywają ważnej roli w codziennym życiu zdecydowanej większości badanych gimnazjalistów. Liczniej i częśsiej swój czas wolny poświęcają oni dla spraw świeckich, jeśli nawet nie biora pod uwagę 1 godziny, którą mogliby przeznaczyć w tygodniu (lub dniu) na udział w nabożeństwie religijnym - mszy świętej ${ }^{29}$.

${ }^{29}$ Zob. W. W e s o ly: Formacja i świadomość misyjna katechizowanej mlodzieży. Studium socjologiczno-pastoralne. Olsztyn 2005 s. 122-123. (Z badań autora wynika, że wśród 1045 ankietowanych licealistów i studentów, niespelna $52 \%$ uczestniczyło w mszy niemal w każdą niedzielę, a $21 \% \mathrm{w}$ dni powszednie $\mathrm{z}$ różną częstotliwością). 


\section{Udzial gimnazjalistów w spowiedzi i Komunii świętej}

Kościól katolicki zobowiązuje pod sankcją winy ciężkiej swoich członków do udziału w spowiedzi przynajmniej jeden raz w roku, zwlaszcza z okazji Wielkiej Nocy. Obowiązek ten dotyczy wszystkich katolików, którzy już przystapili do pierwszej spowiedzi i Komunii świętej ${ }^{30}$. Świadomość tego obowiązku maja także mlodzi katolicy, w tym młodzież gimnazjalna. Problem ten uwzględnilem również we wlasnych badaniach, stawiając respondentom cztery pytania: a) $\mathrm{Czy}$ masz świadomość obowiązkowej spowiedzi i Komunii wielkanocnej?; b) Czy sam(a) spelniasz ten obowiazek?; c) Czy i jak często spowiadasz sie poza obowiązkiem wielkanocnym?; d) Jak często przystępujesz do Komunii świętej po odbytej spowiedzi, z wylączeniem Wielkanocy? Wypowiedzi respondentów na te pytania ukaże tabela zbiorcza.

Tabela 7. Spowiedź wielkanocna i okolicznościowa gimnazjalistów

\begin{tabular}{|c|c|c|c|c|c|c|c|c|c|c|}
\hline \multirow{2}{*}{$\begin{array}{l}\text { Respondenci } \\
\text { Udział w spowie- } \\
\text { dzi }\end{array}$} & \multicolumn{2}{|c|}{ Kobiety } & \multicolumn{2}{|c|}{ Mężczyźni } & \multicolumn{2}{|c|}{ Gim. wiejskie } & \multicolumn{2}{|c|}{$\begin{array}{l}\text { Gim. miej- } \\
\text { skie }\end{array}$} & \multicolumn{2}{|c|}{ Razem } \\
\hline & $\mathrm{L}$. & $\%$ & L. & $\%$ & L. & $\%$ & L. & $\%$ & $\mathrm{~L}$. & $\%$ \\
\hline \multicolumn{11}{|c|}{ Swiadomość obowiazku: } \\
\hline Posiada w pełni & 227 & 35,7 & 81 & 25,4 & 138 & 37,4 & $\begin{array}{c}17 \\
0\end{array}$ & 29,0 & 308 & 32,2 \\
\hline $\begin{array}{l}\text { Posiada częścio- } \\
\text { wo }\end{array}$ & 154 & 24,2 & 78 & 24,5 & 98 & 26,6 & $\begin{array}{c}13 \\
4 \\
\end{array}$ & 22,9 & 232 & 24,3 \\
\hline Nie ma zupelnie & 238 & 37,4 & 142 & 44,5 & 117 & 31,7 & $\begin{array}{c}26 \\
3 \\
\end{array}$ & 44,9 & 380 & 39,8 \\
\hline Brak odpowiedzi & 17 & 2,7 & 18 & 5,6 & 16 & 4,3 & 19 & 3,2 & 35 & 3,7 \\
\hline \multicolumn{11}{|c|}{ Wypelnianie obowiązku: } \\
\hline W każdym roku & 238 & 37,4 & 92 & 28,8 & 141 & 38,2 & $\begin{array}{c}18 \\
9\end{array}$ & 32,2 & 330 & 34,6 \\
\hline $\begin{array}{l}\text { Nie w każdym } \\
\text { roku }\end{array}$ & 80 & 12,6 & 31 & 9,7 & 46 & 12,6 & 65 & 11,1 & 111 & 11,6 \\
\hline Nie pamiętam & 39 & 6,1 & 27 & 8,5 & 27 & 7,3 & 39 & 6,7 & 66 & 6,9 \\
\hline $\begin{array}{l}\text { Nie spełniam od } \\
\text { lat }\end{array}$ & 253 & 39,8 & 148 & 46,4 & 136 & 36,8 & $\begin{array}{c}26 \\
5 \\
\end{array}$ & 45,2 & 401 & 42,0 \\
\hline Brak danych & 26 & 4,1 & 21 & 6,6 & 19 & 5,1 & 28 & 4,8 & 47 & 4,9 \\
\hline \multicolumn{11}{|c|}{ Spowiedź w ciągu roku oprócz wielkanocnej: } \\
\hline Do 3 razy w roku & 139 & 21,8 & 69 & 21,6 & 74 & 20,0 & $\begin{array}{c}13 \\
4 \\
\end{array}$ & 22,8 & 208 & 21,8 \\
\hline Od 4 do 8 razy & 207 & 32,5 & 81 & 25,4 & 121 & 32,8 & $\begin{array}{c}16 \\
7\end{array}$ & 28,5 & 288 & 30,2 \\
\hline Powyżej 9 razy & 78 & 12,3 & 32 & 10,0 & 51 & 13,9 & 59 & 10,1 & 110 & 11,5 \\
\hline Wcale (ani razu) & 188 & 29,6 & 118 & 37,0 & 107 & 29,0 & $\begin{array}{c}19 \\
9\end{array}$ & 34,0 & 306 & 32,0 \\
\hline Brak danych & 24 & 3,8 & 19 & 6,0 & 16 & 4,3 & 27 & 4,6 & 43 & 4,5 \\
\hline Ogółem & 636 & 100,0 & 319 & 100,0 & 369 & 100,0 & $\begin{array}{c}58 \\
6 \\
\end{array}$ & 100,0 & 955 & 100,0 \\
\hline
\end{tabular}

$\mathrm{Na}$ początku analizy zwróćmy uwagę na stopień świadomości obowiązku spowiedzi wielkanocnej wśród badanych gimnazjalistów. W hipotezie empirycz-

${ }^{30}$ Zob. J. K a s z te la n: Sprawowanie sakramentu pokuty. Kraków 1992; S. W i te k: Sakrament pojednania. Poznań 1979; A. Ma r co l: Pokuta i sakrament pokuty. Opole 1992; M. $\mathrm{P}$ a s t u s z k o: Sakrament pokuty i pojednania. Kielce 1999. 
nej zakładałem, iż świadomość tę posiada dominujący odsetek respondentów, niezależnie od plci i typu gimnazjum. Niestety, hipoteza ta nie potwierdzila swojej trafności w wynikach badań empirycznych. Pelną świadomość tego obowiązku posiada niespełna $1 / 3$ respondentów, a częściowo $1 / 4$. Łącząc te dwa wskaźni$\mathrm{ki}$, można ryzykownie stwierdzić, że $56,5 \%$ badanych gimnazjalistów wie w stopni „optymalnym” o ciązacym na nich jako mlodych katolikach obowiązku spowiedzi i Komunii wielkanocnej. Świadomość tę liczniej mają dziewczęta $(59,9 \%)$ niż chlopcy $(49,9 \%)$ oraz liczniej gimnazjaliści wiejscy $(64 \%)$ niż miejscy $(51,9 \%)$.

Świadomość obowiązku spowiedzi wielkanocnej bezpośrednio rzutuje na częstotliwość jego realizacji przez badanych gimnazjalistów. $Z$ danych wynika, że ponad 2/5 badanych, w tym więcej chlopców (o 6,6\%) niż dziewcząt nie spowiada się w okresie wielkanocnym od kilku lat, wlacznie z tymi, którzy ostatni raz spowiadali się $\mathrm{w}$ dniu swojej pierwszej spowiedzi i Komunii. Pozostali respondenci $(46,2 \%)$ wypelniali obowiazek wielkanocny, albo regularnie co roku $(34,6 \%)$, albo tez nieregularnie $(11,6 \%)$. Obowiazek tek liczniej spelniaja dziewczęta $(50 \%)$ niż chłopcy $(38,5 \%)$ oraz liczniej gimnazjaliści wiejscy $(50,8 \%)$ niż miejscy $(43,3 \%)$.

Religijność zaangażowana przejawia się także w częstotliwości udzialu katolików w spowiedzi poza-wielkanocnej i w Komunii świętej. O taki udzial pytalem moich respondentów. $Z$ deklaracji ich wynika, że $1 / 3$ nie spowiada się $w$ ogóle od kilku lat, a w dodatku nie odczuwaja oni zupelnie takiej potrzeby. Pozostali spowiadają się z różną częstotliwością, lecz tylko co dziesiąty więcej niż 10 razy w roku. Ponad 1/5 spowiada się do 3 razy w roku, zaś $1 / 3$ od 4 do 8 razy w roku. Częstotliwość ta jest większa u dziewcząt i mlodzieży wiejskiej, aniżeli u chlopców i młodzieży miejskiej.

Z wielu badań wynika, że katolicy polscy, w tym młodzi, rzadko i w niewielkich odsetkach przystępują do Komunii świętej w niedziele i święta, a nie mówiąc już o dniach roboczych. Nieco lepiej sytuacja ta wygląa z odsetkiem przystępujacych do Komunii w okresie wielkanocnym, który jest w miarę zbliżony do odsetka spowiadających się w tym czasie. Jednak w niektórych badań wynika, że pewien odsetek katolików pomija wtedy spowiedź z różnych powodów, a przystępuje do Komunii, narażając się na konflikt sumienia ${ }^{31}$. Inną sytuacją są rodzinne uroczystości religijne związane choćby z pierwszą Komunią dzieci, podczas której niektórzy rodzice lub chrzestni przyjmują Komunię bez

${ }^{31}$ Zob. J. B a n i a k: Praktyki religijne katolików XX wieku..., art. cyt., s. 292-294. 
spowiedzi („dla dobra dziecka”) ${ }^{32}$, czy też chrzest dziecka, który również stanowi okazję do analogicznego postępowania „nieświadomych” katolików - rodziców i innych czlonków rodziny ${ }^{33}$.

W badaniach własnych interesuję się także udziałem gimnazjalistów w Komunii świętej, zarówno jako obowiązkiem wielkanocnym, jak i jako składnikiem ich gorliwości religijnej. W związku z tym postawiłem i 2 pytania: Czy wlasną Komunię wielkanocną zawsze poprzedzasz spowiedzią święta, czy też przyjmujesz wtedy Komunię bez spowiedzi? Czy i ile razy przyjmujesz Komunię święta po wcześniejszej spowiedzi okazjonalnej? Wypowiedzi gimnazjalistów na te pytania ukaże 8 tabela zbiorcza.

Jeśli porównamy wskaźniki spowiedzi wielkanocnej z wskaźnikami Komunii wielkanocnej badanych gimnazjalistów, bez większego trudu zauważymy, że nieco większy odsetek przystępuje do Komunii $(59,6 \%)$ niż do spowiedzi $(53,1 \%)$. Tę sytuację spotykamy wśród dziewcząt (spowiedź - 56,1\% i Komunia - $61,7 \%$ ) i mężczyzn $(47 \%$ do $55,2 \%)$ oraz wśród uczniów szkól wiejskich $(58,1 \%$ do $62,9 \%)$ i miejskich $(50 \%$ do $57,5 \%)$. Większe są również odsetki przyjmujących Komunię wielkanocną regularnie co roku niż spowiadających się $\mathrm{z}$ tej okazji $\mathrm{z}$ taką częstotliwością $\mathrm{w}$ każdej badanej grupie respondentów dziewcząt o $4,7 \%$, chlopców o $8,5 \%$, uczniów wiejskich o 7,4\% i miejskich o $7 \%$. Jednocześnie zmniejszył się w calej zbiorowości badanej odsetek osób rezygnujacych z Komunii wielkanocnej $(35,5 \%)$ w stosunku do odsetka nie spowiadających się z tej okazji (42\%) o 6,5\%, a także w poszczególnych grupach dziewczęta o $5,6 \%$ i chlopcy o $8,2 \%$, gimnazjaliści wiejscy o $4,8 \%$ i miejscy o $7,5 \%$.

Czym wyjaśnić to dziwne zjawisko? Ryzykowne mogłoby się okazać stwierdzenie, iż wzrósł poziom pobożności u pewnego odsetka badanych gimnazjalistów wiejskich i miejskich. Różnica między tymi wskaźnikami jest dość duża, więc nie można jej zlekceważyć $w$ analizie religijności respondentów. Pewne wyjaśnienie tego zjawiska dają wypowiedzi respondentów na pytanie, czy wcześniej przystępuja do spowiedzi, zanim przyjmą Komunię wielkanocną? Analizując te wypowiedzi, zauważamy, że $13,8 \%$ badanych, w tym $11,5 \%$ dziewcząt i 18,5\% chlopców oraz 12,7\% gimnazjalistów wiejskich i $14,5 \%$ miejskich „niekiedy" przyjmuje Komunię święta bez wcześniejszej spowiedzi w okresie wielkanocnym. Ponadto, $8,7 \%$ badanych ( $w$ tym $7,5 \%, 11 \%, 10,3 \%$,

\footnotetext{
${ }^{32}$ Zob. J. B a n i a k: Desakralizacja obrzędów pierwszej komunii świętej w Polsce. Studium socjologiczne na przykladzie rodzin katolickich w Kaliszu. „Poznańskie Studia Teologiczne”. R. 2005: 18 s. $157-188$.

${ }^{33}$ Zob. J. B a n i k: Zachowania katolików Kalisza dotyczqce chrztu dzieci. „Studia Gnesnensia". R. 2005: 19 s. 353-375.
} 
7,7\%) stwierdza, że „obecnie nie pamięta tego, czy spowiedź poprzedzila ich Komunię wielkanocną. Być może, iż ci respondenci $(13,8 \%)$ trwali przez caly rok (a może i dłużej) w „stanie laski uświęcającej”, czyli nie popelnili grzechu ciężkiego i nie odczuwali potrzeby wyspowiadania się przed Wielkanocą i bezpośrednio w tym okresie przystapili do Komunii świętej?

Tabela 8. Komunia wielkanocna i okolicznościowa gimnazjalistów

\begin{tabular}{|c|c|c|c|c|c|c|c|c|c|c|}
\hline \multirow{2}{*}{$\begin{array}{l}\text { Respondenci. } \\
\text { Udział w } \\
\text { Komunii św. }\end{array}$} & \multicolumn{2}{|c|}{ Kobiety } & \multicolumn{2}{|c|}{ Mężczyźni } & \multicolumn{2}{|c|}{ Gim. wiejskie } & \multicolumn{2}{|c|}{ Gim. miejskie } & \multicolumn{2}{|c|}{ Razem } \\
\hline & L. & $\%$ & $\mathrm{~L}$. & $\%$ & $\mathrm{~L}$. & $\%$ & L. & $\%$ & $\mathrm{~L}$. & $\%$ \\
\hline \multicolumn{11}{|c|}{ Wypelnienie obowiązku wielkanocnego: } \\
\hline $\begin{array}{l}\text { W kazdym } \\
\text { roku }\end{array}$ & 268 & 42,1 & 108 & 33,9 & 165 & 44,8 & 211 & 36,0 & 376 & 39,4 \\
\hline $\begin{array}{l}\text { Nie w } \\
\text { każdym roku }\end{array}$ & 86 & 13,5 & 41 & 12,8 & 40 & 10,8 & 87 & 14,8 & 127 & 13,3 \\
\hline $\begin{array}{l}\text { Nie pamię- } \\
\text { tam }\end{array}$ & 39 & 6,1 & 27 & 8,5 & 27 & 7,3 & 39 & 6,7 & 66 & 6,9 \\
\hline $\begin{array}{l}\text { Nie przystę- } \\
\text { puje od lat }\end{array}$ & 217 & 34,2 & 122 & 38,2 & 118 & 32,0 & 221 & 37,7 & 339 & 35,5 \\
\hline Brak danych & 26 & 4,1 & 21 & 6,6 & 19 & 5,1 & 28 & 4,8 & 47 & 4,9 \\
\hline \multicolumn{11}{|c|}{ Spowiedź przed Komunią wielkanocną: } \\
\hline $\begin{array}{l}\text { Zawsze } \\
\text { wcześniej }\end{array}$ & 483 & 76,0 & 202 & 63,3 & 262 & 71,0 & 423 & 72,2 & 685 & 71,7 \\
\hline $\begin{array}{l}\text { Niekiedy bez } \\
\text { spowiedzi }\end{array}$ & 73 & 11,5 & 59 & 18,5 & 47 & 12,7 & 85 & 14,5 & 132 & 13,8 \\
\hline $\begin{array}{l}\text { Nie pamię- } \\
\text { tam }\end{array}$ & 48 & 7,5 & 35 & 11,0 & 38 & 10,3 & 45 & 7,7 & 83 & 8,7 \\
\hline Brak danych & 32 & 5,0 & 23 & 7,2 & 22 & 6,0 & 33 & 5,6 & 55 & 5,8 \\
\hline \multicolumn{11}{|c|}{ Komunia po spowiedzi w czasie roku: } \\
\hline Do 3 razy & 189 & 29,7 & 108 & 33,9 & 124 & 33,6 & 173 & 29,5 & 297 & 31,1 \\
\hline $\begin{array}{l}\text { Od } 4 \text { do } 8 \\
\text { razy }\end{array}$ & 168 & 26,4 & 79 & 24,8 & 74 & 20,0 & 173 & 24,7 & 247 & 25,9 \\
\hline $\begin{array}{l}\text { Powyżej } 9 \\
\text { razy }\end{array}$ & 78 & 12,3 & 33 & 10,3 & 48 & 13,0 & 63 & 10,8 & 111 & 11,6 \\
\hline $\begin{array}{l}\text { Na każdej } \\
\text { mszy }\end{array}$ & 124 & 19,5 & 51 & 16,0 & 77 & 20,9 & 98 & 16,7 & 175 & 18,3 \\
\hline Nigdy & 77 & 12,1 & 48 & 15,0 & 46 & 12,4 & 79 & 13,5 & 125 & 13,1 \\
\hline Ogółem & 636 & 100,0 & 319 & 100,0 & 369 & 100,0 & 586 & 100,0 & 955 & 100,0 \\
\hline
\end{tabular}

Jeśli tak byłoby naprawdę, wówczas świadczyłoby to o ich głębokiej pobożności. Być może, iż nie mają oni „wyczucia” lub odpowiedniej wiedzy teologicznej i etycznej o typach grzechów i o „obciążeniu” nimi wlasnego sumienia, zaś ten stan ich świadomości moralnej pozwolił im na przyjęcie Komunii świętej bez uprzedniej spowiedzi? Być może, iż zdecydowali się na Komunię bez spowiedzi z innych jeszcze przyczyn i powodów, jak choćby z obawy przed opinią rodziców i katechetów, a może nawet kolegów? Może naśladują oni własnych rodziców lub innych krewnych, którzy lekceważą istotę i rolę spowiedzi i bez niej przystępują do Komunii świętej, dając im zly przykład osobisty?

$Z$ drugiej strony należy podkreślić, iż dominujący odsetek badanych gimnazjalistów $(71,7 \%)$ w okresie wielkanocnym wpierw spowiada się, a dopiero póź- 
niej przystępuje do Komunii świętej. W ten sposób liczniej postępują dziewczęta (o $12,3 \%$ ) niż chlopcy, jak i gimnazjaliśsi miejscy (o $1,2 \%$ ) niż wiejscy ${ }^{34}$.

\section{Modlitwa indywidualna gimnazjalistów}

Z licznych badań opinii publicznej wynika, że dzisiejsi katolicy i chrześcijanie ,zagubili” potrzebę modlitwy, że modlą się coraz rzadziej i w coraz mniejszych odsetkach w różnych grupach społecznych, ujawniając w ten sposób oslabienie wrażliwości religijnej, oslabienie i zanikanie wlasnej wiary religijnej. Zjawisko to ma wiele przyczyn u swego podloża, jednak sekularyzacja codziennego życia i dążenie do sukcesu, a ostatnio przesadne liczenie ludzi na samych siebie, sa wskazywane jako powody główne laicyzowania się sfery religijnej ludzi. Podobna sytuację badacze dostrzegają obecnie u znacznego odsetka młodzieży polskiej, zwlaszcza uczącej i studiującej, która preferuje świecki styl by$\mathrm{cia}^{35}$.

Zagadnieniem modlitwy indywidualnej interesuję się także we wlasnych badaniach dotyczących religijności gimnazjalistów, stawiając im dwa pytania: a) Czy sami widza sens modlitwy we wlasnym życiu codziennym?; b) Jak często modlili się w tygodniu poprzedzającym badania? Wypowiedzi ich na te pytania ukaże 9 tabela zbiorcza.

Opinie badanych gimnazjalistów dotyczace sensu i potrzeby modlitwy w życiu ludzi, jak i w ich osobistym życiu, są dość zróżnicowane i dalekie, można powiedzieć, od oczekiwań katechetów i duchowieństwa parafialnego. W ocenie znacznego odsetka respondentów, modlitwa indywidualna „może okazać się przydatna", albo też ,jest potrzebna" bardziej innym ludziom, zwlaszcza starszym wiekowo, aniżeli im samym, jako osobom mlodym. Być może, iż gimnazjaliści postrzegaja życie bardziej w perspektywie świeckich znaczeń i wartości, a mniej w optyce wartości religijnych? Uczennica drugiej klasy z miejskiego gimnazjum mówi o modlitwie w następujacy sposób: „Modlitwa jest potrzebna mojej babci lub mojej ciężko chorej cioci, bo one sądza, że polepszy im ona życie, czy przywróci utracone zdrowie. Ja wiem, ze tak się nie stanie. Dla mnie taka modlitwa jest nie potrzebna, więc nie modlę się sama, ponieważ nie odczuwam

${ }^{34}$ Zob. W. W e s o ły, dz. cyt., s. 125, tabela 19. (Autor wskazuje, że badana przez niego mlodzież przystępowała do Komunii po spowiedzi według następującej częstotliwości: 1-3 razy (34,2\%); 4-8 razy (29,6\%); 9 i więcej razy ( $11 \%)$; na każdej mszy $(20,4 \%)$; wcale $(4 \%)$.

${ }^{35}$ Zob. F.W. W a w r o: Postawy religijne mlodzieży szkól średnich. W: W. P i w o w a r s k i, W. Z d a n i e w i c z (red.): Z badań nad religijnościa polska. Poznań 1986 s. 215-218; R. C u ry low s ki: Postawy religine mlodzieży ponad-gimnazjalnej wobec religii. W: J. B a n i a k (red.): Religijna i moralna kondycja mlodzieży polskiej, dz. cyt., s. 31-48; M. D ę b s k i: Przejawy „niewidzialnej" religii w religijności mlodzieży akademickiej, tamże, s. 127-148. 
potrzeby modlenia się do nikogo - ani do Boga, ani do Matki Boskiej, czy do Świętego Józefa" (K. 1. 16).

Tabela 9. Modlitwa indywidualna odmawiana przez gimnazjalistów

\begin{tabular}{|c|c|c|c|c|c|c|c|c|c|c|}
\hline \multirow{2}{*}{$\begin{array}{l}\text { Respondenci } \\
\text { Modlitwa indywi- } \\
\text { dualna }\end{array}$} & \multicolumn{2}{|c|}{ Kobiety } & \multicolumn{2}{|c|}{ Mężczyźni } & \multicolumn{2}{|c|}{ Gim. wiejskie } & \multicolumn{2}{|c|}{ Gim. miejskie } & \multicolumn{2}{|c|}{ Razem } \\
\hline & $\mathrm{L}$. & $\%$ & $\mathrm{~L}$. & $\%$ & L. & $\%$ & $\mathrm{~L}$. & $\%$ & L. & $\%$ \\
\hline \multicolumn{11}{|c|}{ Sens i potrzeba modlitwy w życiu człowieka: } \\
\hline Zawsze & 275 & 43,2 & 109 & 34,2 & 205 & 55,5 & 179 & 30,5 & $\begin{array}{c}38 \\
4\end{array}$ & 40,2 \\
\hline Niekiedy (rzadko) & 225 & 35,4 & 103 & 32,3 & 77 & 20,9 & 251 & 42,8 & $\begin{array}{c}32 \\
8\end{array}$ & 34,3 \\
\hline Nie ma sensu & 108 & 17,0 & 82 & 25,7 & 66 & 17,9 & 124 & 21,2 & $\begin{array}{c}19 \\
0\end{array}$ & 20,0 \\
\hline Brak danych & 28 & 4,4 & 25 & 7,8 & 21 & 5,7 & 32 & 5,5 & 53 & 5,5 \\
\hline \multicolumn{11}{|c|}{ Sens i potrzeba modlitwy w życiu gimnazjalistów: } \\
\hline Zawsze & 237 & 37,3 & 92 & 28,9 & 158 & 42,8 & 171 & 29,2 & $\begin{array}{c}32 \\
9\end{array}$ & 34,4 \\
\hline Niekiedy (rzadko) & 231 & 36,3 & 114 & 35,7 & 118 & 32,0 & 227 & 38,7 & $\begin{array}{c}34 \\
5\end{array}$ & 36,1 \\
\hline Nie ma sensu & 137 & 21,5 & 87 & 27,3 & 70 & 19,0 & 154 & 26,3 & $\begin{array}{c}22 \\
4\end{array}$ & 23,5 \\
\hline Brak danych & 31 & 4,9 & 26 & 8,1 & 23 & 6,2 & 34 & 5,8 & 57 & 6,0 \\
\hline \multicolumn{11}{|c|}{ Częstotliwość modlitwy w ostatnim tygodniu: } \\
\hline Codziennie (stale) & 140 & 22,0 & 58 & 18,2 & 93 & 25,2 & 105 & 17,9 & $\begin{array}{c}19 \\
8\end{array}$ & 20,7 \\
\hline Od 1 do 4 razy & 122 & 19,2 & 72 & 22,6 & 54 & 14,5 & 140 & 23,9 & $\begin{array}{c}19 \\
4 \\
\end{array}$ & 20,3 \\
\hline Od 5 do 7 razy & 146 & 16,7 & 41 & 12,9 & 58 & 15,7 & 89 & 15,2 & $\begin{array}{c}14 \\
7\end{array}$ & 15,4 \\
\hline 8 i więcej razy & 83 & 13,0 & 36 & 11,2 & 61 & 16,5 & 58 & 9,9 & $\begin{array}{c}11 \\
9\end{array}$ & 12,5 \\
\hline $\begin{array}{l}\text { Nie modlę się } \\
\text { wcale }\end{array}$ & 148 & 23,3 & 88 & 27,6 & 77 & 20,8 & 159 & 27,1 & $\begin{array}{c}23 \\
6 \\
\end{array}$ & 24,7 \\
\hline Brak danych & 37 & 5,8 & 24 & 7,5 & 26 & 7,0 & 35 & 6,0 & 61 & 6,4 \\
\hline Ogółem & 636 & 100,0 & 319 & 100,0 & 369 & 100,0 & 586 & 100,0 & $\begin{array}{c}95 \\
5\end{array}$ & 100,0 \\
\hline
\end{tabular}

Badania wykazaly, że jedynie $1 / 5$ respondentów, w tym liczniej chłopcy (o $8,7 \%$ ) niż dziewczęta, stwierdza, że modlitwa nie ma sensu i jest zbędna w życiu czlowieka. Pozostali respondenci wyrazili pogląd odmienny, akceptując w pelni $(40,2 \%)$ lub warunkowo $(34,2 \%)$ sens i potrzebę modlitwy w życiu każdego czlowieka. Lącznie, więc, taka potrzebe modlitwy dostrzega $74,5 \%$ badanych osób, w tym $78,6 \%$ dziewcząt i $66,5 \%$ chłopców oraz $76,4 \%$ gimnazjalistów wiejskich i 73,3\% miejskich.

Ten optymistyczny akcent nieco słabnie wtedy, kiedy analizujemy deklaracje respondentów dotyczące potrzeby modlitwy w ich osobistym życiu. Zbędność modlitwy akcentuje $23,5 \%$ badanych, czyli więcej o $3,5 \% \mathrm{w}$ porównaniu $\mathrm{z}$ jej potrzebą w życiu innych ludzi. Jednocześnie zmalal do $34,4 \%$ odsetek twierdzących, ze modlitwa zawsze ma sens w ich życiu, a wzrósł odsetek akceptujących rolę modlitwy warunkowo. Sytuacje taką widzimy zarówno u dziewcząt (mniej o 5,9\%) i chłopców (mniej o 5,3\%), jak u gimnazjalistów wiejskich (mniej 
o $12,7 \%$ ) i miejskich (mniej o 1,3\%), którzy zawsze widzieli potrzebę modlitwy w swoim życiu.

Takie postrzeganie sensu modlitwy ma wplyw na częstotliwość odmawiania jej przez badanych gimnazjalistów. Stąd w tygodniu poprzedzajacym badania modlili się oni z różną częstotliwością. Ponad $1 / 4$ stwierdziła, że od lat nie modli się wcale, ponieważ „nie odczuwa takiej potrzeby”, czy też modlitwa ,nie ma żadnego sensu". Opinię taką nieco liczniej wyrazili chlopcy i uczniowie gimnazjów miejskich. Co piaty respondent modlił się codziennie i taki sam odsetek do czterech razy w tygodniu. Osoby modlace się codziennie, czynia to nawet kilka razy, jednak niektórzy maja watpliwości, czy modlą się poprawnie i czy Bóg „wyslucha" ich modlitw? Bez watpienia, w osobistym życiu tych młodych ludzi zabrakło w licznych przypadkach miejsca i czasu dla modlitwy, nie przywiązywali większej wagi do jej roli we wlasnym życiu. Miejsce religii i modlitwy zajęly te elementy świeckie, które bardziej im odpowiadaly z wielu punktów widzenia, a także powiązane $z$ kryzysem ich tożsamości osobowej ${ }^{36}$. Natomiast dla respondentów religijnych modlitwa jest ważnym czynnikiem, który nadaje sens ich życiu, lączy ich z Kościołem i parafia, uczy ich kochać Boga i Jezusowi powierzać wlasne problemy i troski ${ }^{37}$.

\section{Indeks praktyk religijnych gimnazjalistów}

Indeks jest określoną miarą danego zjawiska, ulokowanego w danym czasie, miara, która wskazuje na poziom dynamiki tegoż zjawiska w ustalonych warunkach. Budowanie indeksu jest operacją ściśle statystyczną, która pozwala zgromadzić niezbędne wskaźniki i nadać im odpowiednią wartość.

Tworzac indeks praktyk religijnych badanych gimnazjalistów, biorę pod uwagę cztery podstawowe praktyki: mszę świętą niedzielna, spowiedź i Komunię świętą oraz modlitwę indywidualną. Tym czterem praktykom religijnym nadaję umownie wartość liczbowa, żeby w ten sposób ustalić poziom intensywności wypelniania ich przez gimnazjalistów. Analizę tego zjawiska ukazuje 10 tabela zbiorcza.

${ }^{36}$ Zob. W. We soly, dz. cyt., s. 121. (Autor informuje, ze częstotliwość modlitwy indy widualne jego respondentów jest następująca: $1-4$ razy w tygodniu $(23,9 \%) ; 5-7$ razy $(34,5 \%)$; 8 i częściej (19,7\%); nie liczy (12,5\%); wcale się nie modli (8,4\%). Liczniej nie modlą się chłopcy $(14,5 \%)$ niż dziewczęta $(4,9 \%)$.

${ }^{37}$ Zob. J. P r z y b y $10 \mathrm{w}$ s k i: Znaczenie nowej ewangelizacji dla duszpasterstwa mlodzieży. Studium pastoralne. Lublin 2001. 
Kiedy zsumujemy cztery uwzględnione praktyki religijne, każdy $\mathrm{z}$ respondentów może uzyskać najwięcej 16 punktów, od zera rozpoczynając. Podzielenie punktów przez cztery, umożliwi skonstruowanie typologii respondentów, w której pojawią się również cztery ich kategorie.

Tabela 10. Indeksacja praktyk religijnych badanych gimnazjalistów

\begin{tabular}{|c|c|c|c|}
\hline Rodzaj praktyki religijnej & Okres spelniania & Częstotliwość spelniania & $\begin{array}{c}\text { Wartości w indeksie } \\
\text { według punktacji }\end{array}$ \\
\hline \multirow{5}{*}{ Msza święta } & \multirow{5}{*}{ w miesiącu } & $1-2$ razy & \multirow{5}{*}{$\begin{array}{l}2 \\
3 \\
4 \\
0 \\
0\end{array}$} \\
\hline & & $3-5$ razy & \\
\hline & & 6 i wieced razy & \\
\hline & & Brak (nie spelnia) & \\
\hline & & Brak danych & \\
\hline \multirow{5}{*}{ Spowiedź święta } & \multirow{5}{*}{ w roku } & $1-3$ razy & \multirow{5}{*}{$\begin{array}{l}2 \\
3 \\
4 \\
0 \\
0\end{array}$} \\
\hline & & $4-8$ razy & \\
\hline & & 9 i więcej razy & \\
\hline & & Brak (nie spelnia) & \\
\hline & & Brak danych & \\
\hline \multirow{6}{*}{ Komunia święta } & \multirow{6}{*}{ po spowiedzi } & $1-3 \mathrm{razy}$ & \multirow{6}{*}{$\begin{array}{l}1 \\
2 \\
3 \\
4 \\
0 \\
0\end{array}$} \\
\hline & & $4-8 \mathrm{razy}$ & \\
\hline & & 9 i więcej razy & \\
\hline & & Zawsze do grzechu & \\
\hline & & Brak (nie spelnia) & \\
\hline & & Brak danych & \\
\hline \multirow{6}{*}{ Modlitwa własna } & \multirow{6}{*}{ w tygodniu } & $1-4$ razy & \multirow{6}{*}{$\begin{array}{l}1 \\
2 \\
3 \\
4 \\
0 \\
0\end{array}$} \\
\hline & & $5-7 \mathrm{razy}$ & \\
\hline & & 8 i wiẹce razy & \\
\hline & & Codziennie & \\
\hline & & Brak (nie spelnia) & \\
\hline & & Brak danych & \\
\hline
\end{tabular}

Typologię tę ilustruje tabela 11, uwzględniajacc pleć i typ gimnazjum, w którym uczyli się badani uczniowie.

Wskaźniki tam zamieszczone informuja o trzech ważnych kwestiach: a) dominujący odsetek gimnazjalistów $(86,9 \%)$ spelnia 4 uwzględnione praktyki religijne; b) spelnianie tych praktyk jest dość znacząco zróżnicowane, ponieważ wśród praktykujących gimnazjalistów widzimy trzy odmienne grupy - regularnie praktykujacych (41\%), gorliwie praktykujacych $(24,5 \%)$ i nieregularnie praktykujacych $(21,4 \%)$; c) co siódmy respondent $(13,1 \%)$ zakwalifikowal się do grupy osób, które nie spelniają tych praktyk, albo zaniedbują je w rażący sposób, na granicy calkowitego zarzucania praktyk. Jednak warto ukazać odsetek osób gorliwie spelniających te praktyki religijne, gdyż jest on wysoki w tej zbiorowości, a także przy uwzględnieniu zjawiska kryzysu tożsamości badanych, który dotknąl większość spośród nich, w tym niektórzy przeżywali go bardzo ostro. Co czwarta badana osoba spelnia te praktyki gorliwie ${ }^{38}$.

${ }^{38}$ Zob. W. W e s o 1 y, dz. cyt., s. 257, tabela 48. ( $Z$ badań autora wynika, że wśród jego mlodych respondentów poziom spelniania takich samych praktyk był następujacy: gorliwie $20,8 \%$, regularnie $-44,4 \%$, nieregularnie $-27,7 \%$, nie praktykowało $-7,1 \%$ ). 
Nastepna tabela zbiorcza (11) ukaże wskaźniki praktyk religijnych gimnazjalistów w podziale na ich pleć i typ gimnazjum, zachowując przyjęte 4 ich kategorie.

Tabela 11. Typologia respondentów wedhug ogólnego wskaźnika praktyk

\begin{tabular}{|l|c|c|c|c|c|c|c|c|c|c|}
\hline \multirow{2}{*}{$\begin{array}{l}\text { Respondenci } \\
\text { Poziom prakty- } \\
\text { kowania }\end{array}$} & \multicolumn{2}{|c|}{ Kobiety } & \multicolumn{2}{|c|}{ Mężczyźni } & \multicolumn{2}{|c|}{ Gim. wiejskie } & \multicolumn{2}{|c|}{ Gim. miejskie } & \multicolumn{3}{|c|}{ Razem } \\
\cline { 2 - 13 } & L. & $\%$ & L. & $\%$ & L. & $\%$ & L. & $\%$ & L. & $\%$ \\
\hline Gorliwie & 164 & 25,8 & 70 & 22,0 & 106 & 28,7 & 128 & 21,8 & 234 & 24,5 \\
\hline Regularnie & 289 & 45,4 & 103 & 32,3 & 177 & 48,0 & 215 & 36,8 & 392 & 41,0 \\
\hline Nieregularnie & 120 & 18,9 & 84 & 26,3 & 48 & 13,0 & 156 & 26,6 & 206 & 21,4 \\
\hline Niepraktykujacy & 63 & 9,9 & 62 & 19,4 & 38 & 10,3 & 87 & 14,8 & 125 & 13,1 \\
\hline Ogótem & 636 & 100,0 & 319 & 100,0 & 369 & 100,0 & 586 & 100,0 & 955 & 100,0 \\
\hline
\end{tabular}

Zmienne niezależne: pleć i typ gimnazjum dość znaczaco różnicuja częstotliwość spelniania przez badanych gimnazjalistów wskazanych tu 4 praktyk religijnych. W kategorii gorliwie praktykujących jest więcej o $3,8 \%$ dziewcząt niż chłopców. Dziewczęta sa również liczniejszą grupa (o $13,1 \%$ ) niż chlopcy w kategorii regularnie praktykujacych. Natomiast chłopcy liczniej o $7,4 \%$ od dziewcząt praktykuja nieregularnie, a także oni liczniej o 9,5\% zaniedbali lub zupełnie przestali spelniać te praktyki religijne. Jeśli jeszcze raz zwrócimy uwagę na kategorię osób zaniedbujących praktyki i calkiem nie spelniających ich, to latwo zauważymy, iż dotyczy to niemal $1 / 5$ chłopców oraz niespelna $1 / 10$ dziewcząt, a wskaźniki te sa znaczące w calej badanej zbiorowości gimnazjalistów. Podobnie sytuacja ta ksztaltuje się przy uwzględnieniu zmiennej typu gimnazjum, a wtedy uczniowie szkól wiejskich odznaczaja się większymi wskaźnikami gorliwie i regularnie praktykujacych.

Praktyki religijne socjologowie mierzą także stosując metodę tzw. „kontinuum", która ułatwia ustalenie stopnia natężenia określonej cechy lub występowania pewnego zjawiska, a nadto, pomaga ona też ustalić kierunek jego rozwoju. W moich badaniach praktyki religijne młodzieży gimnazjalnej ujmuje na dwóch krańcach (brzegach) tegoż kontinuum, czyli od bardzo gorliwego spelniania praktyk religijnych, do ich zaniedbywania i niespelnienia. W tym tez celu wcześniej ustalone wskaźniki praktyk ujmuję ostatecznie dychotomicznie: „gorliwie i regularnie praktykujący" i „nieregularnie praktykujący i niepraktykujący”. Stosujac metodę korelacji ${ }^{39}$ badanego zjawiska z przyjętymi zmiennymi, obliczam iloraz, który jest wynikiem stosunku „bardziej” do „mniej” praktykujących. Iloraz ten umożliwia odpowiedź na pytanie, kto spośród respondentów „bardziej”, a kto „mniej” spelnia te praktyki religijne? Korelacja umożliwia ustalenie wzajemnego związku między dwiema zmiennymi ${ }^{40}$, zaś zmiana wartości jednej zmiennej

\footnotetext{
${ }^{39}$ Zob. K. O le c h n i c k i, P. Z a ł ę c k i: Stownik Socjologiczny. Toruń 1998 s. 101-102.

${ }^{40}$ Zob. H.M. B l a l o c k: Statystyka dla socjologów. Warszawa 1977 s. 304-402.
} 
skorelowanej wywoluje zmianę wartości drugiej zmiennej. Korelacja między zmiennymi może posiadać trojaki wynik: a) dodatni, a wtedy przyrost wartości jednej zmiennej powoduje przyrost wartości drugiej zmiennej; b) ujemny, a wtedy przyrost wartości jednej zmiennej wywoluje spadek wartości drugiej zmiennej; c) pozorny, a wtedy między zmiennymi nie ma żadnej zależności ${ }^{41}$. Inaczej mówiąc, tablica korelacyjna ukazuje rozkład liczebności i ich skale oraz wspólzależności między nimi ${ }^{42}$.

Korelację przyjętych praktyk religijnych gimnazjalistów z kilkoma podstawowymi zmiennymi ukazuje 12 tabela zbiorcza. Wskaźniki ujęte w tej tabeli korelacyjnej informuja, że w badanej zbiorowości gimnazjalistów większość stanowią osoby „lepiej” praktykujące, wespól z gorliwie spelniającymi te praktyki. Natomiast osoby praktykujace ,gorzej", czyli „,słabo" praktykujące lub „wcale" niepraktykujące, są tu w mniejszości. Ustalony iloraz 1,98 oznacza tu ,średnią" normę realizacji praktyk przez badanych gimnazjalistów. Ci respondenci, których iloraz jest wyższy od średniej normy praktykowania, gorliwie spelniaja te praktyki religijne. $Z$ kolei respondenci, których iloraz jest mniejszy od średniej $(1,98)$, praktyki religijne realizują niesystematycznie, albo w ogóle już przestali je realizować.

W analizie tej warto zwrócić uwagę szczególną na związki zachodzace między zmienną deklaracji poziomu wiary i częstotliwością spelniania praktyk religijnych przez badanych gimnazjalistów.

Tabela 12. Korelacja praktyk religijnych gimnazjalistów ze zmiennymi społecznymi

\begin{tabular}{|c|c|c|c|c|}
\hline \multirow{3}{*}{ Zmienne niezależne } & \multirow{3}{*}{$\mathrm{N}=100 \%$} & \multicolumn{2}{|c|}{ Spełnianie praktyk } & \multirow{3}{*}{$\begin{array}{l}\text { Iloraz: } \\
\text { bardziej-mniej }\end{array}$} \\
\hline & & "gorliwie" & "słabo, wcale" & \\
\hline & & \multicolumn{2}{|c|}{ w odsetkach } & \\
\hline Ogółem & 955 & 66,5 & 33,5 & 1,98 \\
\hline \multicolumn{5}{|l|}{ Płeć: } \\
\hline Driewczęta & 636 & 71,2 & 28,8 & 2,47 \\
\hline Chłopcy & 319 & 59,8 & 40,2 & 1,48 \\
\hline \multicolumn{5}{|l|}{ Wiek: } \\
\hline $14-15$ & 508 & 69,7 & 30,3 & 2,30 \\
\hline $16-17$ & 447 & 62.4 & 37,6 & 1,65 \\
\hline \multicolumn{5}{|l|}{ Rodzaj gimnazjum: } \\
\hline Wiejskie & 369 & 72,7 & 27,3 & 2,66 \\
\hline Miejskie & 586 & 67,6 & 32,4 & 1,53 \\
\hline \multicolumn{5}{|l|}{ Deklaracja wiary: } \\
\hline Glęboko wierzacy & 171 & 80,7 & 19,3 & 4,18 \\
\hline Wierzacy & 578 & 71,7 & 28,3 & 2,53 \\
\hline Watpiący i obojętny & 141 & 39,8 & 60,2 & 0,66 \\
\hline Niewierzący & 37 & 10,6 & 89,4 & 0,11 \\
\hline \multicolumn{5}{|l|}{ Typ rodziny: } \\
\hline Pełna (zintegrowana) & 765 & 68,5 & 31,5 & 2,17 \\
\hline Rozbita (rozwód) & 132 & 58,4 & 41,6 & 1,40 \\
\hline Samotny rodzic & 58 & 62,2 & 37,8 & 1,64 \\
\hline
\end{tabular}

${ }^{41}$ Zob. N. G o 1 d m a n: Wstep do socjologii. Poznan 1997 s. 358.

${ }^{42}$ Zob. Z. R o g o z i ń s k i: Z metodyki statystycznej badań spolecznych. Łódź 1955 s. 53. 


\begin{tabular}{|l|l|l|l|l|}
\hline Miejsce zamieszkania: & \multicolumn{5}{|l|}{} \\
\hline Wieś & 387 & 70,5 & 29,5 & 2,38 \\
\hline Małe miasto & 259 & 66,7 & 33,3 & 2,00 \\
\hline Duże miasto & 309 & 60,8 & 39,2 & 1,55 \\
\hline
\end{tabular}

Najwyższym wskaźnikiem spelniania praktyk odznaczają się osoby „głęboko" wierzace $(4,18)$ oraz osoby „,w normie" wierzace $(2,53)$. Natomiast poniżej średniej $(1,98)$ znajduja się osoby niewierzące $(0,11)$ oraz obojętne i wątpiace religijnie $(0,66)$. Powyżej średniej są także praktyki dziewcząt $(2,47)$, praktyki uczniów liczacych 14-15 lat $(2,30)$, gimnazjalistów wiejskich $(2,66)$, mieszkańców wsi $(2,38)$ i malych miast $(2,00)$ i dzieci z rodzin zintegrowanych $(2,17)$. Z kolei praktyki niektórych chlopców, uczniów w wieku 16-17 lat, gimnazjalistów miejskich, mieszkańców dużego miasta, dzieci z rodzin rozbitych wychowywanych przez samotnych rodziców znajduja się poniżej ustalonego ilorazu $(1,98)$. Te wlaśnie cechy i okoliczności sprzyjaja lub nie sprzyjaja realizacji praktyk religijnych przez badanych tu gimnazjalistów ${ }^{43}$.

\section{V. Świadomość religijna gimnazjalistów}

Analiza poziomu wierzeń i praktyk religijnych badanych gimnazjalistów świadczy z dużą dozą prawdopodobieństwa o poziomie ich świadomości religijnej. Wykorzystujacc wskaźniki empiryczne wierzeń i praktyk religijnych dla całej ich zbiorowości, jak i dla obu grup wynikajacych z podzialu na pleć i typ gimnazjum, można ukazać stosowne poziomy ich świadomości religijnej. Powstaje tu pytanie, czy na poziom świadomości religijnej gimnazjalistów mają wplyw takie zmienne niezależne, jak: płeć, wiek, typ rodziny, miejsce stalego zamieszkania i wychowania, poziom wierzeń religijnych i poziom praktyk religijnych, kryzys tożsamości osobowej?

Zależności między tymi zmiennymi ustalamy z pomocą miernika Q Kendala. Stosując ten miernik, ustalilem stopień zależności lub poziom oddzialywania 8 zmiennych na poziom świadomości religijnej gimnazjalistów.

1. Pleć respondentów

Liczba Q dla zmiennej płci wynosi + 0,248, która oznacza, że poziom zależności między płcią respondentów a „mniejsza” lub „większa” ich świadomością religijna jest mało istotny. Miernik ten informuje, że dziewczęta na tym etapie rozwoju jedynie nieznacznie mają wyższą świadomość religijną niż chłopcy. Taki poziom ukazują także liczby realne respondentów obojga plci.

2. Wiek respondentów

${ }^{43}$ Zob. W. W e s o 1y, dz. cyt., s. 259, tabela 49. ( $Z$ badań autora wynika, że poniżej średniej uplasowały się praktyki religijne chłopców, a powyżej praktyki dziewczat, zaś zdecydowanie powyżej są praktyki osób glęboko wierzących). 
Dla zmiennej wieku liczba Q wynosi $+0,161$ i oznacza, iż między dwoma przyjętymi poziomami wieku respondentów (14-15 i 16-17) a poziomem ich świadomości religijnej nie zachodzi zależność statystyczna na znaczącym poziomie. Inaczej mówiąc, nie ma większej różnicy między poziomem świadomości religijnej gimnazjalistów „mlodszych” i ,starszych”, a przeciwnie, poziom ten jest w miarę wyrównany.

3. Typ gimnazjum

Dla zmiennej typu gimnazjum liczba Q wynosi $+0,121$ i oznacza, że między typem gimnazjum, w którym uczą się respondenci, a ich „mniejsza” lub „większą" świadomością religijną brak zależności istotnej, ponieważ liczba ta jest mniejsza od liczby wyjściowej miernika Q, która wynosi: $+<0,200-0,999$ lub $>0,200-0,999$. Typ gimnazjum nie ma więc większego wplywu na poziom świadomości religijnej gimnazjalistów - jest ona podobna w szkolach wiejskich i miejskich.

4. Miejsce stalego zamieszkania respondentów

Dla zmiennej stałego miejsca pobytu respondentów liczba $\mathrm{Q}$ wynosi $+0,366 \mathrm{i}$ oznacza, że poziom zależności między ich stalym pobytem na wsi lub w mieście (typem), a „mniejszą" lub „większą" świadomością religijna jest istotny na średnim poziomie, ponieważ liczba ta jest większa od liczby wyjściowej Q. Środowisko wiejskie bardziej sprzyja wyższemu poziomowi świadomości religijnej gimnazjalistów niż środowisko miejskie, zwlaszcza wielkomiejskie.

5. Typ rodziny respondentów

Dla zmiennej typu rodziny, w której żyją i rozwijają się gimnazjaliści, liczba Q wynosi $+0,883$ i oznacza, iż między typem rodziny (zintegrowanej i zdezintegrowanej), a „mniejszą" lub „większą” świadomością religijną gimnazjalistów zachodzi bardzo istotna zależność statystyczna, jako że miernik Q dla tej zmiennej jest wielokrotnie większy od miernika wyjściowego. Rodzina zintegrowana $i$ pelna zdecydowanie lepiej sprzyja rozwojowi religijności dzieci, aniżeli rodzina zdezintegrowana, rozbita i niepelna.

6. Wierzenia religijne respondentów

Dla zmiennej poziomu wiary religijnej, który deklarują respondenci, liczba Q wynosi $+0,881$ i oznacza, że między poziomem wiary religijnej lub niewiary, a poziomem świadomości religijnej gimnazjalistów zachodzi bardzo istotna zależność statystyczna; miernik ten jest znacznie większy od miernika Q wyjściowego. Im wyższy jest poziom wiary religijnej jednostki, tym większą ma ona świadomość religijną. Osłabienie lub brak wiary wywołuje obojętność religijną, albo wręcz zanik świadomości religijnej u młodych jednostek.

7. Praktyki religijne respondentów

Dla zmiennej typu praktyk religijnych, które spelniaja respondenci, liczba Q wynosi $+0,565$ i oznacza, że między częstotliwościa spelniania praktyk religijnych, a poziomem świadomości religijnej gimnazjalistów zachodzi dość istotna zależność statystyczna; miernik ten jest większy od miernika Q wyjściowego. Im 
systematyczniej jednostka spelnia praktyki religijne, tym wyższy poziom ma jej świadomość religijna. Wplyw praktyk religijnych lączy się ściśle z poziomem wiary w Boga, a oba te czynniki odgrywają najważniejszą rolę w procesie ksztaltowania świadomości religijnej gimnazjalistów.

8. Kryzys tożsamości respondentów

Dla tej zmiennej niezależnej miernik Kendala $Q$ wynosi $+0,528$ i oznacza, ze poziom zależności między radykalnie silnym i umiarkowanym lub brakiem kryzysu tożsamości gimnazjalistów, a „wysokim” lub „,niskim” poziomem ich świadomości religijnej, jest dość istotny statystycznie. Im wyższy jest poziom kryzysu tożsamości osobowej jednostki, tym mniejsza jest jej świadomość religijna, i odwrotnie - im słabszy jest ten kryzys lub występuje jego brak, tym bardziej wzrasta religijna świadomość jednostki. Religijność osób przeżywających kryzys tożsamości jest „anemiczna”, lokuje się na „niskim” poziomie, a ich wiara jest pełna watpliwości, obojętności i niekonsekwencji. Wśród nich jest gros osób, które deklarują wręcz ,niewiarę" i akceptują ateizm.

\section{Podsumowanie}

Wyniki badań zaprezentowane $\mathrm{w}$ tej pracy stanowią zaledwie fragment większej monografii socjologicznej, jednak pozwalają na sformulowanie kilku konstatacji ogólnych, jak i na weryfikację hipotez empirycznych, które przyjąlem w koncepcji tych badań.

Religijność badanych gimnazjalistów ujawnia cechy i poziomy adekwatne do typowych zmian w strukturze i funkcjonowaniu ich osobowości społecznej. Badania potwierdzily trafność tego założenia, wykazując rzeczywiste cechy religijności i kościelności gimnazjalistów, odpowiednie do okresu ich życia i zmian osobowościowych, związanych bezpośrednio z kryzysem ich tożsamości. Religijność tej mlodzieży jest jeszcze „niedojrzala” i podlega ciaglej ewolucji w dwóch kierunkach - pozytywnym i wówczas jednostka w tym wieku próbuje postrzegać religię jako czynnik znaczący w jej życiu osobistym, albo negatywny i wtedy jednostka nastawia się obojętnie lub negatywnie do religii, osłabiając lub eliminując jej rolę we własnym życiu codziennym. Krytyka z jej strony dotyczy przede wszystkim autorytetów religijnych i moralnych, które sa jej narzucone w Kościele. Religijność tej grupy mlodzieży jest niestabilna, chwiejna w postawach i slabo poglębiona intelektualnie, mimo, iż większość uczestniczy w lekcjach religii w gimnazjum. Wiedza religijna jej jest pelna braków i nieścisłości, plytka i powierzchowna, wielu zagadnień ona nie rozumie i nie potrafi wyjaśnić, jak choćby istoty sakramentów, a bardziej traktuje je jako ,graniczne progi" do przejścia na kolejny etap swojej biografii i spolecznych znaczeń. 
Dominujący odsetek badanych gimnazjalistów wiejskich i miejskich uczestniczy w szkolnym nauczaniu religii. Jednakże nie wszyscy są zadowoleni z tego, że „muszą" brać udzial w tym ,dodatkowym” przedmiocie szkolnym, gdyż tak wlaśnie ponad $2 / 5 \mathrm{z}$ nich rozumie i traktuje nauczanie religii. Jedynie niespelna $1 / 5$ spośród nich widzi w tym ,przedmiocie" szkolna katecheze, a ponad $3 / 5$ uważa, że w „,szkole świeckiej nie ma miejsca na katechezę, ponieważ w takiej szkole brak odpowiedniego klimatu i nastroju religijnego, który można znaleźć w kościele lub w sali katechetycznej". Młodzież ta odróżnia wiedzę religijna, jaka daje jej szkola, od formacji religijno-duchowej, którą może przejść wylącznie w środowisku kościelnym, zwlaszcza w parafii, pod kierunkiem osób duchownych.

Większość badanych gimnazjalistów deklaruje wlasne przywiązanie do zasad wiary katolickiej, a blisko $1 / 5$ ocenila jako „wysoki" poziom wlasnej wiary religijnej. Wysoki jest także odsetek respondentów (ponad 1/2), którzy w każda niedzielę uczestniczą w obowiązkowej mszy świętej. Udzial ich w mszy w dni robocze nie jest już tak eksponowany w calości życia religijnego.

Poziom świadomości religijnej badanych gimnazjalistów w ujęciu ogólnym nie jest, niestety, na najwyższym poziomie, i dość ściśle lączy się z etapem ich rozwoju osobowego, czyli z etapem kryzysu tożsamości. Kryzys ten, jak już zaznaczylem, jest zmienną niezależna, która istotnie warunkuje poziom świadomości religijnej badanych gimnazjalistów, zarówno ich wierzenia, jak i praktyki religijne, a także nastawienie do instytucji religijnych.

Z pastoralnego punktu widzenia wychodząc, religijność tej grupy młodzieży można wliczyć do tzw. „ryzyka” procesu jej rozwoju, czyli należy pamiętać, iż prawidlowy rozwój świadomości religijnej gimnazjalistów istotnie zależy od wlaściwego pokierowania rozwojem ich osobowości, od pozytywnego podejścia osób znaczacych (autorytetów) do ich problemów i oczekiwań, od wiedzy naukowej i religijnej katechetów oraz metod przekazu jej w szkole i w parafii, wreszcie od „meandrów” życia spolecznego w kraju i w Kościele, które - wbrew pozorom - gimnazjaliści uważnie obserwują zarówno na poziomie lokalnym (parafia, wioska, miasto, dzielnica), jak i na poziomie globalnym (Kościól, państwo, kraj), lecz często nie rozumieją ich istoty i przebiegu. Osoby znaczące winny spełnić te oczekiwania młodzieży i pomóc jej w odnalezieniu własnego miejsca w Kościele i w spoleczności świeckiej. 